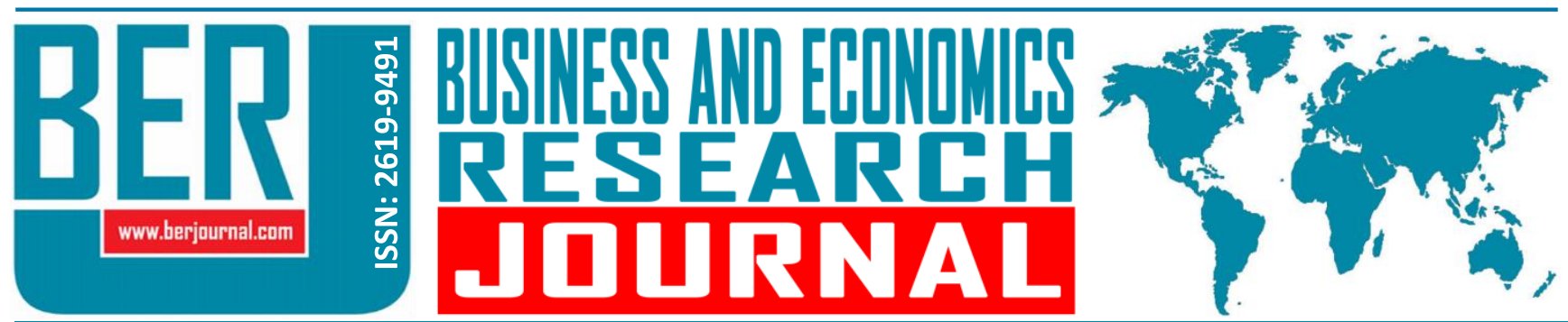

Business and Economics Research Journal Vol. 10, No. 3 Special Issue, 2019, pp. 597-616 doi: 10.20409/berj.2019.188

\title{
Petrol Fiyatları, Petrol Tüketimi ve Finansal Gelişmişlik İlişkisi ${ }^{1,2}$
}

\section{Hasim Bagci ${ }^{\mathrm{a}}$}

Öz: Petrol dünya ülkeleri için alternatifi olmayan ve sürekli ihtiyaç duyulan bir enerji kaynağıdır. Bu nedenle petrol tüketen ülkelerin fiyat değişimlerinden nasıl etkilendikleri ve finansal durumları günümüzde cevap bekleyen sorulardan biridir. Bu çalışmada petrol fiyatları, petrol tüketimi ve finansal gelişmişlik ilişkisi araştırılmıştır. Çalışmada OECD ülkeleri analiz edilmiş ve 1980-2015 yılları arası yıllık verilerden yararlanılmıştır. Araştırmanın amacı OECD ülkelerinde petrol fiyatları, petrol tüketimi ve finansal gelișmişlik ilişkisini tespit etmektir. Çalıșmada 17 OECD ülkesi analiz edilmiş ve panel veri analizi yöntemi kullanılmıştır. Panel veri analizinin tüm aşamaları uygulanmış ve değişkenler arasında eşbütünleşme ilişkisi saptanamadığı için panel VAR analizi kullanılarak analize devam edilmiştir. Panel VAR analizine ait diğer alt analizler olan Granger nedensellik analizi, varyans ayrıștırması ve etki-tepki fonksiyonları yapılarak analiz gerçekleștirilmiștir. Analiz sonucunda; petrol tüketiminden finansal gelişmişliğe doğru ve petrol fiyatlarından petrol tüketimine doğru tek yönlü nedensellik ilișkileri tespit edilmiștir. Bu saptamalar sonucunda aralarında anlamlı ilișki tespit edilen; petrol tüketimindeki artışın finansal gelișmişlik seviyesini yükselttiği ve petrol fiyatlarındaki artışın ise petrol tüketimini düşürdügü etki-tepki fonksiyonlarıyla gösterilmiștir. Bulunan bu sonuçlar literatürdeki çalıșmaları desteklemiștir.

\section{The Relationship among Oil Prices, Oil Consumption and Financial Development}

Abstract: Oil is an energy source having no alternative and always demanded. Since this is the case, how oil consumer countries are affected by price changes and their financial situations are one of the questions waiting for an answer. In this study, the relationship between oil prices, oil consumption and financial development, has been explored. In the study, OECD countries have been analyzed and yearly data between 1980-2015 has been used. The aim of the study is to designate the effect of oil prices and oil consumption over financial development. In the study, 17 $O E C D$ countries have been analyzed and the method of panel data analysis has been used. All steps of panel data analysis have been applied and since no cointegration relationship was detected, the analysis was sustained by using panel VAR analysis. Other sub-analysis belonging to panel VAR analysis like Granger causality analysis, variance decomposition and impulseresponse functions have been used to complete the analysis. At the end of the analysis, one-way causality relationships have been detected from oil consumption to financial development and from oil prices to oil consumption. As a result of these findings, as there is a meaningful relationship; it has been shown by impulse-response functions that the upside in oil consumption increases financial development level and the upside in oil prices decreases oil consumption. All these findings supported the studies in the literature.
Anahtar Sözcükler: Petro Fiyatları, Petrol Tüketimi, Finansal Gelişmişlik, Panel VAR Analizi, Granger Nedensellik Analizi

JEL: B26, F65, 013, Q42

Gelis 05 Şubat 2019

Düzeltme : 06 Mart 2019

Kabul : :08 Mart 2019

Tür

: Araştırma

Keywords: Oil Prices, Oil Consumption, Financial Development, Panel VAR Analysis and Granger Causality Analysis

JEL: B26, F65, O13, Q42

Received : 05 February 2019

Revised : 06 March 2019

Accepted : 08 March 2019

Type : Research 


\section{Giriş}

Enerji günlük hayatta insanların yaşamını sürdürebilmesi için gereksinim duyulan temel ihtiyaçtır. Çünkü enerji olmaksızın insanoğlunun üretim, tüketim, ulaşım gibi hayatın her anında yapması gereken günlük yaşama ait aktivitelerini gerçekleştirmesi imkânsızdır. Bu nedenle enerji; insanoğlunun hayatına devam edebilmesi için zaruri ihtiyacıdır. Dünyada tüketilen farkı enerji kaynakları bulunmaktadır. Bu enerji kaynaklarından yenilenebilir enerji kaynaklarının kullanımı hem çevre hem de insan sağlığı için önerilse de bu kaynakların yetersizliği, yenilenemez (petrol, doğalgaz, kömür vb.) kaynakların kullanımını zorunlu hale getirmektedir. Bu çalışmanın temel konularından olan petrol; geçmiş yıllarda hem maliyeti düşük hem de çok fazla olduğu için yakıt olarak kullanılmıştır. Bu nedenle; petrole ulaşmak ve petrolü elde etmek için ülkeler arası savaşlar çıkmıştır. Petrol, ülke ekonomileri için o kadar önem arz etmektedir ki; ülkeler petrol fiyatlarındaki değişimden minimum düzeyde etkilenmek için ekonomi politikalarını petrol fiyatlarına göre düzenlemektedir. Çünkü petrol fiyatlarındaki olası artış veya azalış tüm ekonomik değişkenleri etkilediği için ülkelerin ekonomik dengelerini bir anda değiştirebilmektedir. Petrolün ülkeler için belirleyici olduğu bir dünya ekonomisinde petrolün yerini alabilecek alternatif bir enerji kaynağının ortaya çıkarılması oldukça önemlidir ancak yakın gelecekte petrolü ikame edecek düzeyde bir enerji kaynağının bulunmasının imkânsız olduğu tahmin edilmektedir. Bu nedenle; gelecekte petrolün tükenme riski göz önüne alınarak ülkelerin mevcut enerji rezervlerini etkin ve verimli kullanmaları gerekmektedir.

Bu çalışmada petrol fiyatları, petrol tüketimi ve finansal gelişmişlik arasındaki ilişkiyi tespit etmek amaçlanmıştır. Bu nedenle nedensellik analizi yapılarak değişkenler arasındaki ilişkinin yönü belirlenmiştir. Ayrıca hangi değişkenler arasında ilişki olmadığı hangi değişkenlerin birbirini tek yönlü veya çift yönlü etkilediği sorularına cevaplar aranmıştır. Literatürde ekonomik büyüme-enerji tüketimi ve ekonomik büyüme-finansal gelişmişlik çalışmaları oldukça fazladır. Ancak enerji ve finansal gelişmişlik ilişkisini inceleyen çalışma sayısı ise çok azdır. Dünya ülkeleri ihtiyacı olan enerjiyi petrolle karşılamaktadır ve petrol kullanan ülkelerin finansal geliş̧şşlik düzeyini görmek için araştırmada bu konu üzerine odaklanılmıştır. Araştırmada kullanılan örneklem grubu; OECD ülkeleridir. 1980-2015 yılları arası zaman dilimi yıllık veriler kullanılarak analiz gerçekleştirilmiştir.

\section{Literatür İncelemesi}

Yapılan araştırmalar kapsamında literatürde finansal gelişmişlik ve büyüme arasındaki ilişkiyi inceleyen araştırmalar ile büyüme ve enerji tüketimi arasındaki ilişkiyi inceleyen çalışmaların sayısı da oldukça fazladır; ancak finansal gelişmişlik ve enerji tüketimi arasındaki ilişkiyi inceleyen çalışmalar sınırlı sayıdadır. Bu araştırmada enerji tüketimine ilave olarak enerji fiyatları da eklenmiştir. Böylece fiyatlar ve tüketim ile finansal gelişmişlik arasındaki ilişki incelenmiş ayrıca tüm enerji kaynakları değil petrol tüketimi ve petrol fiyatları ile finansal gelişmişlik ilişkisi ölçülmüştür.

Finansal gelişmişlik kavramı literatüre son yıllarda giren bir kavram olduğu için çalışmalar 2000 ve sonraki yıllarda gerçekleşmiştir.

Brunnschweiler (2009)'a göre; Genelleştirilmiş Momentler Metodu (GMM) kullanılmış ve OECD'ye üye olmayan 119 ülke araştırılmıştır. 119 ülkenin yenilenebilir enerji ve finansal gelişmişlik değişkenlerine ait 1980-2006 yılları arası yıllık verileri kullanılmıştır. Finansal gelişmişliğin ölçümü için 3 değişken kullanılmış olup, bunlar: "banka mevduat varlıkları/GSYH", "özel sektör kredileri/GSYH" ve "likit yükümlülükler/GSYH"dir. Yenilenebilir enerjiyle ilgili olarak 1998 yılında imzalanan Kyoto Protokolü de analize kukla değişken olarak eklenmiştir. Yapılan analiz sonucunda finansal geliş̧şşliğin enerji tüketimini pozitif etkilediği ve kukla değişken olan Kyoto Protokolü'nün de enerji piyasasını olumlu etkilediği bulgularına ulaşılmıştır.

Sadorsky (2010) 1990-2006 yılları arası 22 ülkeyi incelemiş; ancak 1990-2006 yılında ülkelerin tüm verileri olmadığı için dengesiz panel kullanmıştır. Enerji tüketimi olarak kişi başına tüketilen petrol miktarını "kg" cinsinden almıştır. Finansal gelişmişlik göstergeleri: yabancı doğrudan yatırım, "banka mevduat varlıkları/GSYH", "borsa kapitalizasyonu/GSYH", "borsa toplam işlem değeri/GSYH" ve "borsa devir hızı"dır. Kullanılan yöntem GMM yöntemidir. Bu yöntemle yapılan analizden elde edilen bulgu; çift yönlü nedensellik 
ilişkisinin varlığıdır ve enerji tüketimi ve finansal gelişmişliğin birbirlerini karşılıklı etkilediği sonucuna varılmıştır. Ancak "yabancı doğrudan yatırım" ve "banka mevduat varlıkları/GSYH" değişkenlerinin finansal gelişmişlik üzerine etkisinin olmadığını saptamıştır.

Sadorsky (2011) Orta ve Doğu Avrupa'da ekonomik açıdan lider olan 9 ülkeyi analiz etmiştir. 19962006 yılları arası yıllık veriler yardımıyla bu çalışma gerçekleştirilmiş olup, analiz edilen ülkeler: Bulgaristan, Hırvatistan, Estonya, Kazakistan, Litvanya, Romanya, Sırbistan, Slovenya ve Ukrayna'dır. Enerji tüketimi verileri bir önceki çalışmasıyla aynı iken (kişi başına tüketilen petrol miktarı kg) finansal gelişmişlik göstergeleri farklılaşmıştır. Finansal gelişmişliği borsa ve banka olarak ikiye bölmüştür. Dört borsa ve üç banka göstergesi olmak üzere toplam 7 farklı değişken kullanılmıştır. Banka göstergeleri: "finansal sistem mevduatları/GSYH", "banka mevduat varlıkları/GSYH", "likit yükümlülükler/GSYH" ve "özel krediler/GSYH'dir. Borsa göstergeleri ise "borsa kapitalizasyonu/GSYH", "borsa işlem hacmi/GSYH" ve "borsa devir hızı"dır. Analizde Sadorsky (2010) çalışmasındaki gibi GMM yöntemini kullanmıştır. Sonuç olarak; banka göstergeleri ile enerji tüketimi arasında anlamlı ve pozitif bir ilişki belirlenirken, borsa göstergelerinden borsa devir hızı ile enerji tüketimi arasında pozitif bir ilişki saptanmıştır.

Shahbaz ve Lean (2012) Tunus'taki enerji tüketimi ile finansal gelişmişlik arasındaki ilişkiyi test etmişlerdir. Enerji tüketimi verileri (kişi başına tüketilen petrol miktarı $\mathrm{kg}$ ) ve finansal gelişmişlik göstergesi “özel sektör kredileri/GSYH'dir. 1971-2008 yılları arasını kapsayan analizde yıllık verilerden yararlanılmıştır. Kullanılan yöntem Granger nedensellik testidir ayrıca uzun dönemli ilişkiyi test etmek için kısıtsız hata düzeltme modeli (UECM: Unrestricted Error Correction Model) kullanılmıştır. Elde edilen sonuç ise uzun dönemde her iki değişken arasında çift yönlü nedensellik ilişkisidir.

Yao (2013) finansal gelişmişlik, ekonomik büyüme ve gelir eşitsizliği ilişkisini incelemiştir. Bu çalışma 5 önemli soruya cevap aramıştır ve bu sorular: "Kişi başına düşen gelir belli bir seviyeye ulaştığında eşitsizlik önce artıp daha sonra azalmakta mıdır? Geliri adaletli dağıtan ülkelere göre gelir eşitsizliği olan ülkelerde ekonomik büyüme daha yavaş mıdır? Ekonomik büyüme ve gelir eşitsizliğinin göstergeleri birbirine benzemekte midir? Finansal gelişmişlik büyüme odaklı mıdır? Finansal gelişmişlik zengine mi yoksa fakire mi daha yakındır?" Çalışmanın sonuçları; ekonomik büyüme ve gelir eşitsizliği ilişkisinin oldukça karmaşık olduğunu ve net sonuçlara ulaşılamadığını ayrıca ekonomik büyüme ve gelir eşitsizliğinin belirleyicilerinin de benzer olmadığını, finansal gelişmişliğin büyümeyi olumsuz etkilediğini ve finansal gelişmişliğin gelir eşitsizliğini ortadan kaldırmaya yönelik bir kavram olmadığını aksine zengin için daha yararlı olduğunu belirtmektedir.

Boutabba (2014) Hindistan'da finansal gelişmişlik, gelir, ticaret ve enerjinin karbon emisyonuna etkisi incelemiştir. 1971-2008 yılları arası yıllık verilerden yararlanılmış, değişkenler arasındaki uzun dönemli ilişkiler ve nedensellik ilişkileri araştııımıştır. Finansal geliş̧işlik ve karbon emisyonu arasında uzun dönemli pozitif ilişki bulunmuştur. Bu durum finansal gelişmişliğin çevresel bozulmayı tetiklemesi olarak ifade edilmiştir. Ayrıca çalışmada finansal gelişmişlikten karbon emisyonuna ve enerjiye doğru tek yönlü nedensellik ilişkisi saptanmıştır. Tüm bu sonuçlardan yola çıkarak; finansal sistemin mevcut faaliyetlerinde çevre boyutunu dikkate alması gerektiği vurgulanmıştır.

Chang (2015) finansal gelişmişlik ve gelirin enerji tüketimine etkisini incelemiştir. Çalışmada 53 ülkenin 1999-2008 yılları arası yıllık verilerinden yararlanılmış ve panel regresyon analizi kullanılmıştır. Ayrıca ülkeler kendi içinde yüksek gelirli olan ve olmayan ülkeler olarak ikiye ayrılmış, finansal gelişmişlik göstergeleri olarak ise özel sektör kredisi, yurtiçi kredi, borsa işlem hacmi ve borsa devir hızı kullanılmıştır. Yüksek gelirli ülkelerde enerji tüketiminin geliri belirli bir eşik değerine kadar sürekli arttırdığı, düşük gelirli ülkelerde enerji tüketiminin finansal gelişmişliği arttırdığı (finansal gelişmişlik göstergeleri olarak hem yurtiçi krediler hem özel sektör kredileri kullanılırsa) belirlenmiştir. Enerji tüketiminin ise düşük gelirli ülkelerde finansal gelişmişliği azalttığı, yüksek gelirli ülkelerde arttırdığı (finansal gelişmişlik göstergeleri olarak borsa devir hızı ve borsa işlem hacmi kullanılırsa) tespit edilmiştir. Bu sonuçlara göre kullanılan finansal gelişmişlik değişkeninin değişkenler arasındaki ilişkiyi etkilediği saptanmıştır.

Contuk ve Güngör (2016)'ya göre; finansal gelişmişlik ile ekonomik büyüme ilişkisi araştırılmıştır. Bu çalışmada Türkiye örnekleminde 1998-2014 yılları arasındaki 3 aylık veri setleri kullanılmıştır. Ekonomik 
büyüme göstergesi olarak reel GSYH; finansal gelişmişlik göstergesi olarak "M2 para arzı/reel GSYH", "özel sektöre verilen krediler/reel GSYH" ve "Borsa i̇stanbul işlem hacmi/reel GSYH" kullanılmıştır. Analizde kullanılan yöntem ise Asimetrik nedensellik testidir. Bu testin sonucunda; ekonomik büyümeden finansal gelişmişliğe doğru tek yönlü nedensellik ilişkisi tespit edilmiştir.

Demirci (2017) finansal gelişmişlik ile özel sektör Ar-Ge harcamaları ilişkisini ölçmüştür. Bu ölçüm, Türkiye'nin 1990-2014 yıllık verileri kullanılarak gerçekleştirilmiştir. Analiz tekniği olarak eşbütünleşme, nedensellik, etki-tepki ve varyans ayrıştırması kullanılmıştır. Uygulanan ekonometrik analizler sonucunda; finansal gelişmişlik ve özel sektör Ar-Ge harcamaları arasında pozitif yönlü eşbütünleşme ve uzun dönemde finansal gelişmişlikten Ar-Ge giderlerine doğru nedensellik ilişkileri belirlenmiştir.

Aydın ve Esen (2017) fazla enerji tüketiminin ekonomik büyümeye zarar verip vermediğini Türki Cumhuriyetler için incelemiştir. Ayrıca enerji tüketiminin ekonomik büyüme üzerindeki etkisinin enerji yoğunluğu düzeyine bağlı olup olmadığı araştırımıştır. Araştırmada dinamik panel eşik değeri analizi kullanıımışır. Araştırma 1991-2012 yılları arasını kapsamaktadır. Araştırmanın sonucunda; eşik değerinin üzerindeki enerji tüketiminin ekonomik büyümeyi negatif etkilediği; ancak eşik değerin altında ise enerji tüketiminin ekonomik büyümeyi pozitif etkilediği tespit edilmiştir. Bu bulgular; enerji tüketiminin, sadece enerji yoğunluğunun belirli bir eşiğine kadar ekonomik büyümeye faydalı olduğunu ortaya koymaktadır; eşik seviyesinin ötesinde tüketim, büyümeyi olumsuz yönde etkileme eğilimindedir. Bu bağlamda, geçiş ekonomisindeki politika yapıcılar enerji politikalarını belirlerken enerji yoğunluğu bağlamında eşik seviyelerini göz ardı etmemelidir.

Aydın ve Esen (2018) enerji tüketimi içerisinde enerji yoğunluğu seviyesinin büyüme üzerindeki etkisini geçiş ekonomileri için incelemişlerdir. Araştırmada dinamik panel eşik analizi kullanılmıştır. 1991-2013 yılları arası 12 Bağımsız Devletler Topluluğu ülkesi için araştırma gerçekleştirilmiştir. Araştırmada eşik değer 0,44 olarak tespit edilmiştir. Bu değerin üzerindeki enerji tüketimi ekonomik büyümeyi geciktirirken, bu değerin altındaki enerji tüketimi ise ekonomik büyümeyi arttırmaktadır. Bu sonuçlar; enerji yoğunluğunun eşik seviyesinin ekonomik büyüme üzerinde belirleyici bir faktör olduğunu ve yeni enerji politikaları oluşturulurken enerji yoğunluğuna daha fazla dikkat edilmesini gerektiğini kanıtlamaktadır.

\section{Araştırma Problemi}

Araştırma problemini belirlemeden önce konuyla ilgili literatür taranmış ve ekonomik büyüme ile enerji tüketimi, ekonomik büyüme ile finansal gelişmişlik arasında çok sayıda çalışma bulunmuştur. Ancak finansal gelişmişlik ile petrol fiyatları ve tüketimi arasındaki ilişkiyi inceleyen çalışma literatürde çok az ve sınırı sayıdadır. Bu nedenle; araştırma problemi: "petrol fiyatları, finansal gelişmişlik ve petrol tüketimi arasındaki ilişkinin ortaya konulması" şeklinde belirlenmiştir.

Araştırmanın amacı; petrol fiyatları, petrol tüketimi ve finansal gelişmişlik arasındaki ilişkiyi belirlemektir. Değişkenlerin hangilerinin birbirini etkilediğini tespit etmek amacıyla nedensellik analizi yapılmış, değişkenler arasında çift yönlü mü, tek yönlü mü etkileşim olduğu, hangi değişkenlerin birbirini etkileyip etkilemediğini belirlemek bu araştırmanın temel amacını oluşturmaktadır.

Finansal gelişmişlik kavramı son yıllarda ortaya çıkan bir kavramdır ve finans piyasalarının, finansal kurumların ve finansal araçların gelişmesi anlamına gelmektedir. Finansal gelişmişliğin ölçülmesi ülkelerin finansal açıdan ne durumda olduğunu görmek ve finansal anlamda önlemler ve kararlar alırken tedbirli davranmak açısından önem arz etmektedir. Finansal gelişmişlik kavramını çalışmanın diğer değişkenleriyle (petrol fiyatları ve tüketimi) birleştirmek çalışmanın literatüre katkısı açısından oldukça önemlidir. Çünkü dünyadaki tüm ülkelerin enerji ihtiyaçları bulunmaktadır ve bu enerjinin çoğunu petrolle karşılamaktadırlar. Bu nedenle petrol, ülkeler için şu anda ikamesi olmayan enerji kaynaklarındandır ve petrol fiyatı da sürekli değişkendir. Bu nedenle petrole bağımlı ülkelerin finansal durumu merak edilmektedir.

Bu araştırmada; petrole bağımlı ülkelerin petroldeki fiyat değişimlerinden finansal açıdan etkilenip etkilenmediği, petrol tüketiminin finansal gelişmişlik düzeylerini arttırıp arttırmadığı, petrol fiyatlarına bağıı olarak petrol tüketimi miktarının değişim gösterip göstermediği sorularına cevaplar aranmıştır. 
Araştırmanın evreni tüm dünya ülkeleri ve tüm yıllardan ibaret iken örneklem ise veriler yetersiz olduğu için küçültülmüştür. Araştırmanın örneklemi 17 OECD ülkesinden oluşmakta ve 1980-2015 yılları arasını içermektedir.

Araştırmanın verilerine farklı internet sitelerinden ulaşılmıştır. Petrol tüketimi verileri IEA'nın yayınlamış olduğu verilerdir, petrol fiyatları verilerine OECD’nin sitesinden ulaşılmış ve veriler OECD ülkelerinin ham petrol ithalat fiyatlarıdır. Petrol fiyatları belirlenirken, GSYH deflatörü kullanılarak fiyat hesaplanmış ve baz yıl olarak 1970 yılı verisi 100 kabul edilerek fiyat oluşturulmuştur. Finansal geliş̧mişlik verilerine ait olarak kullanılan değişkenlere Dünya Bankası internet sitesinden erişilmiş ve Topsis yöntemi yardımıyla finansal gelişmişlik endeksi oluşturulmuştur. Elde edilen veriler; panel veri biçimine dönüştürülerek Stata programıyla analiz edilmiştir. Analizde kullanılan tüm verilerin, oluşturulan endeksin ve kullanılan programların doğru ve güvenilir olduğu varsayılmıştır.

Araştırma kapsamında ülkelere ait finansal gelişmişlik endeksi skorları, petrol fiyatları ve petrol tüketimleri verileri kullanılmıştır. Bu verilerden yaralanarak, OECD ülkeleri analiz edilmiştir. OECD ülkeleri; finansal istikrarı koruma, halkın yaşam seviyesini iyileştirme, sürekli ve dengeli ekonomik gelişim sağlayan politikaya destek ve yardım, işsizliğin ortadan kaldırılması, ekonomik genişleme politikasının uyandırılması ve dünya ticaretinin geliştirilmesine destek verilmesi gibi konularda önderlik ettiğinden dolayı seçilmiştir. Ayrıca $A B D$ 'nin petrol tüketimi diğer OECD ülkelerinden oldukça fazladır bu nedenle verilerin kontrolü yapıldığında hem normal dağılımı bozan ülkenin $A B D$ olduğu tespit edilmiş hem de $A B D$ 'nin petrol tüketimi standart sapmadan oldukça farklılık göstermiştir. Bu nedenle; verilerine erişilemeyen ve verileri yayınlanmayan OECD ülkeleri (16 ülke) ile ABD'nin petrol tüketimi veri setinde sorun oluşturduğu için araştırmadan çıkarılmıştır. Araştırmada 17 OECD ülkesi kullanılmıştır. Bu ülkeler: Avustralya, Avusturya, Belçika, İsviçre, Almanya, Danimarka, İspanya, Birleşik Krallık, İlanda, Yunanistan, İtalya, Japonya, Hollanda, Norveç, Türkiye, Portekiz ve İsveç'tir.

Araştırmada kullanılan değişkenler: petrol fiyatları, petrol tüketimi ve finansal gelişmişlik endeksi skorlarıdır. Araştırmadaki verilerin hepsi ikincil veridir. Bu verilerden 1980-2015 yılları arasındaki dolar/varil birimli petrol fiyatlarına www.data.oecd.org sitesinden ulaşılmışır. 1980-2015 yılları arasındaki milyon ton birimli petrol tüketimine ise www.iea.org sitesinden erişilmiştir. Finansal gelişmişlik göstergeleri olarak: "özel sektör kredileri/GSYH", "yurtiçi krediler/GSYH", "GSYH" ve enflasyon rakamları kullanılmıştır. Finansal gelişmişlik göstergelerinin hepsine www.data.worldbank.org sitesinden erişilmiştir. Erişilen bu verilerden finansal gelişmişlik endeksi oluşturulmuştur, çünkü bu göstergelerin hepsi finansal gelişmişliğin alt değişkenidir.

\section{Araştırmanın Metodolojisi}

Yapılan araştırmada elde edilen verilere göre birçok ülke olduğu için zaman serisi analizi yapılması imkânsızdır. Birden çok yıl olduğu için yatay kesit analizi de yapılamaz; ancak her yıl için tek tek yatay kesit analizi yapılabilmektedir. Hem birden çok yıl hem de birden çok ülke olduğu için panel veri analizi yapılması en uygunudur. Panel veriler yardımıyla iktisadi ilişkileri tahmin etmek için kullanılan yöntem panel veri analizi yöntemidir.

\section{Araştırmanın Modeli}

Araştırmada panel veri analizi kullanıldığı için kurulan model panel veri modelidir. Panel veri modeli; analizde kullanılan veriler yardımıyla oluşturulan ve panel veri setleri ile tahminlenen regresyon modelidir. Panel veri modeliyle ilgili çalışmalar ilk olarak; Hildreth (1950), Kuh (1959), Grunfeld ve Griliches (1960), Zellner (1962), Balestra ve Nerlove (1966) ve Swamy (1970) tarafından yapılmış; ancak panel veri modelinin tüm aşamaları 1990'lı yıllardan itibaren kullanılmaya başlanmıştır (Tatoğlu, 2013: 4; Güriş, 2015: 4).

Panel veri modelleri regresyon modelleri gibi bir bağımlı ve birden çok bağımsız değişkenle kurulmaktadır. Ayrıca ekonometrik bir model olduğu için modelde hata terimi de yer almaktadır. Bir panel veri modeli: $Y_{i t}=\alpha_{i t}+\beta_{i t} X_{i t}+\mu_{i t}$ şeklinde kurulmaktadır. Bu modeldeki i birim sayısını, $t$ ise zaman periyodunu göstermektedir. $Y$ bağımlı değişkeni, $X$ bağımsız değişkeni, $\alpha$ sabit parametreyi, $\beta$ eğim parametresini ve $\mu$ ise 
hata terimini ifade etmektedir. Sabit parametre olarak $\beta_{0}$ sembolü de kullanılabilmektedir. Değişken sayısı arttıkça model farklı şekilde kurulmaktadir. Değişken sayısına göre model: $Y_{i t}=\alpha_{i t}+\beta_{1 i t} X_{1 i t}+\beta_{2 i t} X_{2 i t}+\ldots . .+\beta_{\text {kit }}$ $X_{\text {kit }}+\mu_{\text {it }}$ veya $Y_{i t}=\beta_{0 i t}+\beta_{1 i t} X_{1 i t}+\beta_{2 i t} X_{2 i t}+\ldots .+\beta_{\text {kit }} X_{\text {kit }}+\mu_{i t}$ şeklinde düzenlenmektedir. Bu modellerdeki $k$, parametre ya da diğer bir ifadeyle değişken sayısını göstermektedir (Tatoğlu, 2013: 37; Güriş, 2015: 5).

Yapılan araştırmada kurulan modelde ise 1 bağımlı 2 bağımsız değişken bulunmaktadır. Bağımlı değişken petrol tüketimi (PT) iken; bağımsız değişkenler ise finansal gelişmişlik (FG) ve petrol fiyatlarıdır (PF). Böylece kurulan model: $\mathrm{PT}_{\text {it }}=\beta_{\text {oit }}+\beta_{1 \text { it }} \mathrm{FG}_{\text {it }}+\beta_{2 i t} \mathrm{PF}_{\text {it }}+\mu_{\text {it }}$ şeklinde düzenlenmiştir. Bu modeldeki verileri standardize etmek için logaritmaları alınmıştır. Bunun nedeni Tablo 1'de gösterilmiştir.

Tablo 1. Betimleyici İstatistikler

\begin{tabular}{|c|c|c|c|c|c|}
\hline Değişkenler & Ortalama & Standart Sapma & Minimum & Maksimum & Gözlem Sayısı ve Süre (N/T) \\
\hline PT & 1011,047 & 1222,532 & 80 & 5704 & $612 / 17$ \\
\hline FG & 99,83275 & 54,30319 & 22,82696 & 296,0283 & $612 / 17$ \\
\hline PF & 41,52693 & 30,93875 & 11,7 & 117,8 & $609 / 17$ \\
\hline InPT & 6,366667 & 1,019895 & 4,382027 & 8,648923 & $612 / 17$ \\
\hline InFG & 4,4569629 & 0,5521666 & 3,127943 & 5,690455 & $612 / 17$ \\
\hline InPF & 3,48979 & 0,6638052 & 2,459589 & 4,768988 & $609 / 17$ \\
\hline
\end{tabular}

Betimleyici istatistiklere göre; değişkenlerin logaritmaları alınmadan önceki durumları ile alındıktan sonraki durumları arasındaki fark görülmektedir. Değişkenlerin logaritmaları alınarak değişkenler standardize edilmiş ve değişkenlerin standart sapmaları düşürülmüştür. Çünkü panel veri analizinde değişkenlerin standart sapmalarının yüksek olması modelde problemlere yol açmaktadır. Modelin değişkenlerin logaritmaları alındıktan sonraki hali: InPT it $=\beta_{\text {oit }}+\beta_{1 i t} \operatorname{lnFG}_{i t}+\beta_{2 i t} \operatorname{lnPF} F_{i t}+\mu_{i t}$ şeklindedir. Stata programı kullanılarak yapılan araştırmada model kurulduktan sonra bu modelin anlamlı olup olmadığı ölçülmüştür. Model anlamlı olmadığında diğer aşamaların uygulanması önemsizdir bunun yerine yeni bir model kurularak anlamlılığının ölçülmesi gerekmektedir. Panel veri modelinin anlamlılığı diğer ekonometrik yöntemlerde olduğu gibi regresyon analiziyle belirlenmiştir.

Panel veri seti programa tanımlandıktan sonra kurulan bu modelin anlamlılığı için regresyon analizi yapılmıştır. Regresyon analizi yapılmadan önce modelle ilgili kurulan hipotezler aşağıdaki gibidir:

$\mathrm{H}_{0}$ : Finansal gelişmişlik ve petrol fiyatlarının petrol tüketimi üzerinde etkisi yoktur.

$\mathrm{H}_{1}$ : Finansal gelişmişlik ve petrol fiyatlarının petrol tüketimi üzerinde etkisi vardır.

Analizin sonuçları Tablo 2'de gösterilmiştir.

Tablo 2. Modelin Anlamlılığının Test Edilmesi

\begin{tabular}{|c|c|c|c|c|c|c|}
\hline \multicolumn{7}{|c|}{$\begin{array}{l}\text { Grup değişkeni: Ülkeler } \\
\text { Gözlemlenen veri sayısı: } 609 \\
\text { Gözlemlenen grup sayısı: } 17 \\
\text { Grup başına veri sayısı: minimum: } 33 \text {; ortalama: } 35,8 ; \text { maksimum: } 36 \\
\text { Korelasyon (u_i, Xb): 0,000 } \\
\text { Olasılık değeri: } 0,000\end{array}$} \\
\hline InPT & Katsayı & Standart Hata & $z$ & $P>|z|$ & \multicolumn{2}{|c|}{$\begin{array}{c}\text { \% } 95 \text { Güven Aralığı } \\
\text { Minimum / Maksimum }\end{array}$} \\
\hline InFG & 0,1784685 & 0,0207181 & 8,61 & 0,000 & 0,1378618 & 0,2190752 \\
\hline $\ln P F$ & $-0,0440894$ & 0,0131384 & $-3,36$ & 0,001 & $-0,0698401$ & $-0,0183386$ \\
\hline Sabit terim & 5,728024 & 0,2378926 & 24,08 & 0,000 & 5,261763 & 6,194285 \\
\hline $\begin{array}{ll}\text { sigma_u: } & \\
\text { sigma_e: } & \\
\text { rho: } & 0\end{array}$ & $\begin{array}{l}3542623 \\
5686872 \\
264676 \\
\end{array}$ & & & & & \\
\hline
\end{tabular}


Regresyon analizi sonuçlarına göre olasılık değeri (p) 0'dır, Bu nedenle $\% 95$ güven aralığında $(0<0,05)$ $\mathrm{H}_{0}$ hipotezi reddedilmekte, $\mathrm{H}_{1}$ hipotezi kabul edilmektedir. Finansal gelişmişlik ve petrol fiyatlarının petrol tüketimi üzerinde etkisi bulunmaktadır. Özetle; model anlamlıdır. Tablonun diğer verileri incelendiğinde; 17 ülke ve 609 veri analiz edilmiştir. Ayrıca regresyon analizi sonucunda modelin katsayıları da belirlenmiş ve kurulan yeni modelin denklemi;

$\operatorname{lnPT} T_{i t}=5,728024+0,1784685 \operatorname{lnFG}{ }_{i t}-0,0440894 \operatorname{lnPF}_{i t}+(0,93542623+0,15686872)$ şeklinde oluşturulmuştur.

\subsection{Araştırma Modelinin Tahmin Yöntemi}

Araştırma modelinin anlamlı olduğu tespit edildikten sonra araştırma modelinin hangi yöntemle tahmin edileceği belirlenmiştir. Üç tür tahmin yöntemi bulunmaktadır. Bunlar; klasik model, sabit etkiler modeli ve tesadüfi (rassal) etkiler modelidir. Araştırma modeli için hangi tahmin yönteminin kullanılacağı birtakım testlerle belirlenmiştir. Gözlemlenemeyen heterojenite yoksa, F testi ve LM testi sonucunda sıfır hipotezi kabul ediliyorsa en küçük kareler ya da diğer bir ifadeyle klasik model tercih edilmektedir. Gözlemlenemeyen heterojenite varsa sabit etkiler ve klasik model arasında seçim yapabilmek için Hausman testi kullanılmakta ve sıfır hipotezi reddedildiğinde sabit etkiler modeli, kabul edildiğinde ise tesadüfi etkiler modelinin kullanılması uygun olmaktadır.

\subsubsection{Klasik Model}

Havuz modeli ya da havuzlanmış en küçük kareler yöntemi olarak da adlandırılan klasik modelde hem eğim katsayıları hem de sabit katsayılar birimlere ve zamana göre değişmemektedir. Tüm gözlemlerin homojen olduğu varsayılmaktadır, Bu nedenle tüm yatay kesitler için ortak bir sabit terim bulunmakta ve modelin hata terimi birimlere ve zamana göre değişmemektedir.

Bir klasik model: $Y_{i t}=X_{i t} \beta+\mu_{i t}$ ya da $Y_{i t}=\beta_{0}+\sum \beta_{k} X_{k i t}+\mu_{i t}$ şeklindedir.

Araştırmada kullanılan modelin klasik olup olmadığını tespit etmek için bazı testler yapıımış ve bu testlere göre modelin klasik olup olmadığı saptanmıştır. Bu testler çok sayıda olup, bunlardan en önemlileri Stata programında uygulanmıştır. Bu testlerden $\mathrm{F}$ testi, Olabilirlik Oranı testi ve Score testi kullanılmıştır. Birçok sayıda test yapılmasının nedeni modelin klasik olup olmadı̆̆ını onaylamaktır, aslında $F$ testi yaparak araştırma modelinin klasik olup olmadığı tespit edilebilmektedir. Araştırma modelinin klasik olup olmadığını belirlemek için kurulan hipotezler tüm testler için geçerli ve şu şekildedir:

$\mathrm{H}_{0}$ : Tüm birim etkiler sıfıra eşittir ve birim etkiler yoktur.

$\mathrm{H}_{1}$ : Tüm birim etkiler sıfıra eşit değildir ve birim etkiler vardır.

F testinin sonuçları Tablo 3'de gösterilmiştir.

Tablo 3. F Testi

\begin{tabular}{|c|c|c|c|c|c|c|}
\hline \multicolumn{7}{|c|}{$\begin{array}{l}\text { Grup değişkeni: Ülkeler } \\
\text { Gözlemlenen veri sayısı: } 609 \\
\text { Gözlemlenen grup sayısı: } 17 \\
\text { Grup başına veri sayısı: minimum: 33; ortalama: } 35,8 \text {; maksimum: } 36 \\
\text { Korelasyon (u_i, Xb): } 0,2796 \\
\text { F }(2,590): 42,71 \\
\text { p: } 0,000\end{array}$} \\
\hline PT & Katsayı & Standart Hata & $t$ & $\mathrm{P}>|\mathrm{z}|$ & \multicolumn{2}{|c|}{$\begin{array}{c}\text { \% } 95 \text { Güven Aralı̆̆ı } \\
\text { Minimum / Maksimum }\end{array}$} \\
\hline InFG & 0,1773736 & 0,0206842 & 8,58 & 0,000 & 0,1367499 & 0,2179973 \\
\hline $\operatorname{InPF}$ & $-0,0436069$ & 0,0131132 & $-3,33$ & 0,001 & $-0,693611$ & $-0,178526$ \\
\hline Sabit terim & 5,730591 & 0,069946 & 81,93 & 0,000 & 5,593218 & 5,867964 \\
\hline $\begin{array}{l}\text { sigma_u: } \\
\text { sigma_e: } \\
\text { rho: } \\
\text { F }(16,590):\end{array}$ & $\begin{array}{l}093551 \\
5686872 \\
7641588 \\
63,04\end{array}$ & & & & & \\
\hline
\end{tabular}


Sonuçlar incelendiğinde; hata terimleri arasında korelasyon bulunduğu tespit edilmiş ve bu durum, klasik modelin varsayımlarını ihlal etmektedir. Ayrıca modelin $\mathrm{p}$ değeri $0<0,05$ olduğu için $\mathrm{H}_{0}$ hipotezi reddedilmektedir. Bu nedenle model klasik model değildir çünkü modelde birim etkilerin varlığı tespit edilmiştir.

\subsubsection{Sabit Etkiler Modeli}

Araştırma modeli tahmin yöntemlerinden bir diğeri de sabit etkiler modelidir. Sabit etkiler modelinde; katsayılar birimlere ya da birimlere ve zamana göre değişiklik göstermektedir. Bu modeldeki sabit terim katsayının zamana göre sabit olmasını ifade etmekte; ancak katsayı birimlere göre değişmektedir. Her bir değişken ya da birim için farklı bir sabit katsayı bulunmaktadır. Modeldeki eğim parametresi $\left(\beta_{0}\right)$ her yatay kesit değişkeni için aynı kabul edilmektedir, Ayrıca modeldeki bağımsız değişkenlerin hata terimi ile arasında korelasyon ilişkisinin bulunmadığı; ancak birim etki ile korelasyon ilişkisi bulunduğu ve birim etkilerin açıklayıcı değişkenleri etkilediği varsayılmaktadır. Bu açıklamalar doğrultusunda oluşturulacak sabit etkiler modeli: $Y_{i t}=\beta_{0 i}+\sum \beta_{k} X_{k i t}+\mu_{i t}$ şeklinde gösterilmektedir. Bu denklemde $\beta_{0 i}$ değişmekte ve yatay kesit bazında farklılaşmaktadır. Ayrıca sabit etkiler modelinin varsayımları kapsamında modele kukla değişkenler eklenerek model: $Y_{i t}=\beta_{0}+\beta_{1} X_{i t}+y_{2} D_{2 i}+y_{3} D_{3 i}+\ldots,,+y n D n_{i}+\mu_{i t}$ şekline dönüşmektedir. $D$ modele eklenen kukla değişkenleri göstermektedir ve modele eklenebilecek kukla değiş̧en sayısı N-1 (N: değişken sayısı) adettir. Çünkü daha fazla kukla değişken eklendiğinde değişkenler arasında çoklu doğrusal bağlantı sorunu ortaya çıkmaktadır (Hsiao, 2003: 30; Pazarlıoğlu ve Gürler, 2007: 38; Özer ve Çiftçi, 2009: 42; Güriş, 2015: 13-22).

Yapılan araştırmanın modelinin klasik model olmadığı testlerle onaylanmıştır; ancak sabit mi tesadüfi mi olduğu Hausman testiyle belirlenmiştir.

\subsubsection{Tesadüfi Etkiler Modeli}

Panel veri analizinde kullanılan diğer tahmin yöntemi ise tesadüfi ya da rassal etkiler modelidir. Tesadüfi etkiler modelinde birim etkiler ve zaman etkileri rassal olarak incelenmektedir. Tesadüfi etkiler modeli örneklem rassal olarak seçildiğinde ortaya çıkmaktadır. $\mathrm{N}$ çok fazla olduğu zaman tesadüfi etkiler modelinin serbestlik derecesi olumsuz etkilenmektedir. Bu nedenle N'in düşük olması gerekmektedir, Ayrıca; rassal etkiler modelinde birim veya zaman etkileri modelde hata teriminin bir bileşeni olarak gösterilmektedir. Rassal etkiler modelinde birim ve zaman etkileri ile bağımsız değişkenler arasında korelasyon ilişkisi bulunmaması gerekmektedir. Bu modelde birim ve zamana özel katsayılar değil, birim ve zamana özel hata bileşenleri bulunmaktadır. Bu nedenle hata terimi sabit etkiler modelinden farklı olarak $v_{\text {it }}$ $+\mu_{\mathrm{i}}$ şeklinde gösterilmektedir. Bu açıklamalar bağlamında rassal etkiler modelinin gösterimi; $Y_{i t}=\beta_{0 i t}+\beta_{1 i t} X_{1 i t}$ $+\beta_{2 i t} X_{2 i t}+\beta_{\text {kit }} X_{\text {kit }}+\mu_{i}+v_{\text {it }}$ şeklindedir. Rassal etkiler modelindeki $v_{\text {it }}$ tüm hataları göstermekte iken, $\mu_{i}$ ise birim hatayı göstermektedir. Bu model hata bileşenleri modeli olarak da ifade edilebilmektedir. Rassal etkiler modeli Breusch-Pagan LM testi yardımıyla tahmin edilmektedir (Özer ve Biçerli, 2003: 72; Tunay, 2009: 43; Baltagi, 2012: 15; Tatoğlu, 2013: 103-104).

\subsubsection{Hausman Testi}

Araştırmada kullanılacak model tahmin yönteminin klasik model olmadığı belirlendikten sonra modelin sabit etkiler mi tesadüfi etkiler modeli mi olup olmadığı tespit edilmelidir. Bu tespiti yapmak için en sık kullanılan yöntem Hausman tarafından 1978 yılında geliştirilen Hausman testidir. Hausman bu yöntemi literatüre "Specification Tests in Econometrics" isimli çalışması ile kazandırmıştır.Bu yöntemin matematiksel formülizasyonu;

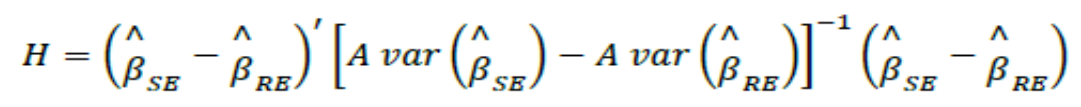

şeklindedir. 
Hausman testinde modelin sabit mi tesadüfi mi olduğunu tespit etmek için kullanılan hipotezler şunlardır:

$H_{0}$ : corr $\left(\mu_{i}, X_{i}\right)=0$ : Rassal etkiler ve sabit etkiler tahmincileri arasında fark yoktur (Rassal etkiler modeli etkindir). etkindir).

$\mathrm{H}_{1}: \operatorname{corr}\left(\mu_{\mathrm{i}}, \mathrm{X}_{\mathrm{i}}\right) \neq 0$ : Rassal etkiler ve sabit etkiler tahmincileri arasında fark vardır (Sabit etkiler modeli

Hausman testi sonucunda belirlenen hipotezlere göre hesaplanan $p<0,05$ ise $\mathrm{H}_{0}$ red, $p>0,05$ ise $\mathrm{H}_{0}$ kabul edilmektedir (Hausman, 1978: 1251-1271).

Hausman testini Stata programında yapabilmek için önceden ifade edilmiş olan sabit ve tesadüfi etkiler modelinin tahminlenip kaydedilmesi gerekmektedir. Bu araştırmada yapılan Hausman testi sonucunda ortaya çıkan sonuç Tablo 4'te gösterilmiştir.

Tablo 4. Hausman Testi

\begin{tabular}{|c|c|c|c|}
\hline \multicolumn{4}{|c|}{$\mathrm{p}: 0,86$} \\
\hline & \multicolumn{2}{|c|}{ Katsayılar } & \\
\hline & (b) & (B) & (b-B) \\
\hline $\operatorname{lnFG}$ & 0,1773736 & $\begin{array}{c}\text { re } \\
0,1784685\end{array}$ & $-0,0010949$ \\
\hline $\ln P F$ & $-0,0436069$ & $-0,0440894$ & 0,0004825 \\
\hline
\end{tabular}

Hausman testi sonucuna göre modelin $p>0,05$ olduğundan dolayı sıfır hipotezi kabul edilmektedir ve bu araştırma modeli için rassal etkiler modelinin kullanılması uygun olmaktadır. Sonuçlara göre kurulan araştırma modeli: $\operatorname{lnFG}$ it $=0,4384923+0,4192685 \operatorname{lnPF}_{i t}+0,4013073 \operatorname{lnPT} T_{i t}+(0,3146753+0,29441826)$ şeklindedir.

\section{Bulgular}

Araştırmanın ulaşmış olduğu bulgulara geçmeden önce araştırmada yatay kesit bağımlılığı olup olmadığı tespit edilmelidir. Çünkü araştırma bulgularının ilk aşaması olan birim kök testleri yatay kesit bağımlılığına göre farklılaşmaktadır. Eğer panel veri analizinde yatay kesit bağımlılığı yoksa 1, nesil birim kök testleri, yatay kesit bağımlılı̆ı varsa 2, nesil birim kök testleri kullanılmaktadır. Bu nedenle araştırma bulgularının ilk kısmı yatay kesit bağımlıı̆ıının tespit edilmesidir.

\subsection{Yatay Kesit Bağımlılı̆̆ı}

Yatay kesit bağımlılığı modeldeki ülkeler, hane halkı, firmalar, gelir vb, gibi değişkenlerin birbirleriyle ilişkisi olmasını ifade etmektedir. Araştırma modelinde yatay kesit bağımlılı̆ı bulunduğunda modeldeki değişkenlerin durağanlıkları uygun testle sınanmalıdır. Yoksa modelde ekonometrik sorunlar ortaya çıkmaktadır. Yatay kesit bağımlıı̆̆ının ölçülmesi için Pesaran, Friedman ve Frees'in testleri bulunmaktadır. Bu testlerin kullanımları gözlem değeri $(\mathrm{N})$, zaman boyutu $(\mathrm{T})$ ve araştırma modelinin dengeli ve dengesiz olmasına göre değişmektedir. Bu çalışmada model güçlü ve dengeli ve $N>T(N=609, T=36)$ olduğu için Pesaran'ın yatay kesit bağımlılığı testi kullanılmıştır. Pesaran yatay kesit bağımlılığı aşağıdaki şekilde formülize edilmiştir (De Hoyos ve Sarafidis, 2006: 482-483; Pesaran, 2012: 3-5).

$$
C D=\sqrt{\frac{2 T}{N(N-1)}}\left(\sum_{i=1}^{N-1} \sum_{j=i+1}^{N} \hat{\rho_{i j}}\right)
$$

2 numaralı formülde CD yatay kesit bağımlılı̆ını ifade ederken, $T$ zaman boyutunu, $N$ ise gözlem sayısını belirtmektedir. Bu şekilde formülize edilen Pesaran'ın hipotezleri şunlardır: 
$\mathrm{H}_{0}$ : Yatay kesit bağımlılığı yoktur.

$\mathrm{H}_{1}$ : Yatay kesit bağımlıı̆ı̆ı vardır.

Bu hipotezler bağlamında araştırma modelinin yatay kesit bağımlılığı sonuçları Tablo 5'te gösterilmiştir.

Tablo 5. Pesaran Testi

Pesaran'ın yatay kesit bağımlılığı değeri: 14,621

p: 0,000

Modelin yatay kesit bağımlılığı sonuçlarına göre; $p$ değeri 0 'dır. Bu sonuçlar Friedman ve Frees'in test istatistiğiyle de karşılaştırılmış ve sonuçlar aynı olasılık değerlerini göstermiştir. Bu nedenle $p<0,05$ olduğu için $\mathrm{H}_{0}$ hipotezi reddedilmiş ve modeldeki değişkenler arasında yatay kesit bağımlılığı bulunduğu tespit edilmiştir. Sonuç olarak; bir sonraki aşamada durağanlık ölçülürken 2, nesil birim kök testlerinin kullanılması önerilmektedir.

\subsection{Durağanlık Kavramı ve Birim Kök Testi}

Durağanlık; analizde ele alınan veri setinin belirli zaman periyodunda sürekli artış ya da azalış göstermediği, verilerin bir yatay eksen boyunca saçılması şeklinde ifade edilmektedir. Bir zaman serisinin ya da panel veri setinin ekonometrik analizi yapılmadan önce serinin durağanlığının araştırılması oldukça önemlidir ve veri setini oluşturan değişkenler durağan değilse farkları alınarak durağanlaştırımaktadır. Çünkü durağan olmayan veri setleriyle analiz gerçekleştirilirse $t$ testi, $F$ testi ve $R^{2}$ değeri sapmalı sonuçlar verebilmekte ve sahte regresyon adı verilen şaşırtıcı ve yanlış sonuçlar ortaya çıkabilmektedir. Zaman serisi ve panel veri setlerinde durağanlık ölçümü birim kök testleri ile yapılmaktadır. Çok fazla sayıda birim kök testi vardır ve birim kök testleri 2 gruba ayrılmaktadır. Birinci kuşak birim kök testleri yatay kesit bağımlı̆̆ını dikkate almazken, ikinci kuşak birim kök testleri yatay kesit bağımlılı̆ını dikkate almaktadır. Birinci kuşak birim kök testleri: Levin, Lin ve Chu testi, Harris ve Tzavalis testi, Breitung testi, Hadri testi, Im, Pesaran ve Shin testi, Fisher ADF testi ve Fisher Philips ve Perron testleri iken, ikinci kuşak birim kök testleri ise Pesaran testi, Bai ve Ng testi, Philips ve Sul testi ve Moon ve Perron testleridir (Güloğlu ve İspir, 2009: 2; Birgili ve Düzer, 2010: 77; Gürkan vd., 2014: 81). Kurulan modelde yapılan testler sonucu yatay kesit bağımlılığının olduğu bulunmuştur. Bu nedenle serinin durağanlığını test etmek için ikinci kuşak panel birim kök testlerini kullanmak gereklidir. Yapılan analizde Pesaran birim kök testi kullanılmıştır. Pesaran (2003) birim kök testinin birinci nesil birim kök testindeki karşılı̆̆ Dickey Fuller birim kök testleridir. Pesaran birim kök testinin modeli aşağıda gösterilmiştir (Tatoğlu, 2013: 223-224):

$$
Y_{i t}=\alpha_{i}+\rho_{i}^{*} Y_{i, t-1}+d_{0} \bar{Y}_{t-1}+d_{1} \Delta \bar{Y}_{t}+\varepsilon_{i t}
$$

Pesaran birim kök testini ölçebilmek için gerekli olan hipotezler şunlardır:

$\mathrm{H}_{0}$ : Seride genel bir birim kök vardır, seri durağan değildir.

$\mathrm{H}_{1}$ : Seride genel bir birim kök yoktur, seri durağandır.

Araştırma modelindeki değişkenlerin $\mathrm{p}<0,05$ ise $\mathrm{H}_{0}$ reddedilmekte ve değişkenlerde birim kök olmadığı ortaya çıkmakta aksi durumda ise değişkenlerin durağan olmadığı tespit edilmektedir. Değişkenler durağan değilse farkları alınarak durağanlaştırılmaktadır. Fark alma ilk fark, ikincil fark vb. biçimde değişken durağanlaşana kadar fark alınmaktadır. Bu araştırmada değişkenlerin birim kök testlerinin sonuçları Tablo 6 'da gösterilmiştir. 
Tablo 6. Birim Kök Testi Sonuçları

\begin{tabular}{|c|c|c|c|c|}
\hline Değişkenler & T Değeri & Olasılık Değeri & Gözlenen Grup ve Veri Sayısı & Zaman Periyodu \\
\hline $\operatorname{lnPT} /$ sabit & $-1,681$ & $0,046^{*}$ & $17 / 578$ & 36 \\
\hline $\operatorname{lnFG} /$ sabit & $-1,755$ & $0,040^{*}$ & $17 / 578$ & 36 \\
\hline $\ln \mathrm{PF} /$ sabit & $-5,856$ & $0,000^{*}$ & $17 / 575$ & 36 \\
\hline
\end{tabular}

Not: Anlamlıık düzeyi \%5 olarak belirlenmiş ve gecikme uzunlukları Akaike Bilgi Kriterine (AIC) göre otomatik olarak seçilmiştir.

Modeldeki değişkenler sabit iken; tüm değişkenler için \%5 anlamlılık düzeyinde sıfır hipotezi reddedilmekte ve birim kök bulunmamaktadır. Bunun anlamı; modeldeki değişkenlerin tümü durağandır ve farklarının alınmasına gerek yoktur. Bu nedenle, panel VAR analizi kullanılarak analize devam edilmiştir.

\subsection{Panel VAR Analizi}

VAR; 1980 yılında Sims'in eşanlı denklem sistemlerine eleştiri olarak ortaya çıkardığı bir modeldir. VAR modelinde; değişkenler arasındaki ilişkileri belirlemek ve değişkenlerin gecikmeli değerlerini ne derece açıkladığını tespit etmek amaçlanmıştır. VAR modeli; rassal şokların değişkenlere olan dinamik etkilerini ortaya çıkarmakta ve eşanlı denklem sistemleri gibi içsel ve dışsal değişken ayrımı yapmamaktadır. Eşanlı denklem sistemlerinde ise değişkenler içsel ve dışsal değişkenler olarak sınıflandırılmaktadır ve içsel değişken, denklemde birbirini karşılıklı etkileyen rassal değişkenler iken; dışsal değişkenler denklemin dışında olan ancak rastgele tespit edilmeyen değişkenlerdir. Dışsal değişkenler, denklemdeki değişkenleri etkileyen ancak modelde yer almayan değişkenlerdir. VAR modeli ise değişkenler arasında içsel ve dışsal ayrımı yapmak yerine değişkenlerin kendi gecikmeleriyle ve diğer değişkenlerin gecikmeli değerleriyle açıklanma yüzdesini belirlemektedir (Greene, 1993: 553; Güriş, 2015: 291).

VAR modelinin gelişimi ekonometri için çok önemli bir ilerlemedir. Çünkü VAR tekniği kullanılan çalışmalarda model kurulurken kısıtlayıcı varsayımlar bulunmamakta ve model iktisat teorisinden bağımsız bir şekilde oluşturulabilmektedir. Modelin daha doğru kurulması sayesinde nedensellik testlerinin güvenilirliği artmaktadır.

Panel VAR modeli ise her zaman bilinen geleneksel VAR modeli ile panel veri modellerinin birleşiminden oluşmaktadır; bir bağımlı, bir bağımsız olmak üzere 2 değişkenden oluşan standart bir panel VAR modeli şu şekilde gösterilmektedir (Love ve Zicchino, 2006: 193-195):

$$
\begin{aligned}
& y_{t}=a_{I}+\sum_{\mathrm{i}=1}^{P} b_{l i} y_{t-i}+\sum_{\mathrm{i}=1}^{P} b_{2 i X t-i}+v_{l t} \\
& x_{t}=c_{l}+\sum_{\mathrm{i}=1}^{P} d_{l i} y_{t-i}+\sum_{\mathrm{i}=1}^{P} d_{2 i X_{t-i}}+v_{2 t}
\end{aligned}
$$

4 numaralı denklemlerde yer alan $p$ değeri gecikme uzunluklarını göstermektedir, $Y$ ve $X$ bağımlı ve bağımsız değişkenlerdir. Birinci denklemde; $\mathrm{y}$ bağımlı değişkeninin kendi gecikmesi ve $\mathrm{x}$ bağımsız değişkenindeki gecikmelerin y üzerindeki etkisi görülmektedir. Bu denklemde a sabit terimi ifade ederken, $v$ hata terimini göstermektedir. İkinci denklemde; $\mathrm{x}$ bağımsız değişkeninin kendi gecikmesi ve y bağımlı değişkenindeki gecikmelerin $\mathrm{x}$ üzerindeki etkisi gösterilmektedir. Bu denklemde $\mathrm{c}$ sabit terimi, $\mathrm{v}$ hata terimini göstermektedir. VAR modelinde; hata terimlerinin gecikmeli değerleri arasında korelasyon ilişkisinin bulunmaması gerekmektedir; ancak bu varsayımın ihmali, modeldeki değişkenlerin gecikme sayıları arttırılarak düzeltilmektedir. VAR modelinde optimal gecikme değerleri; Akaike ve Schwarz bilgi kriterleriyle belirlenmektedir. VAR analizi üç yolla sonuç vermektedir. İlki; F testi yapılarak ortaya konulan Granger nedensellik sonuçları, ikincisi; değiş̧enler arasındaki dinamik etkileri ortaya koyan varyans ayrıştırması ve üçüncüsü; etki-tepki fonksiyonlarıyla değişkenler arasındaki ilişkinin grafiksel gösterimidir (Özgen ve Güloğlu, 2004: 5-6). 
H. Bagci

Teorik olarak anlatılan VAR analizini yapabilmek için öncelikle optimal gecikme değerinin belirlenmesi gereklidir. Optimal gecikme değeri sonuçları Tablo 7'de gösterilmiştir.

Tablo 7. Optimal Gecikme Değeri Sonuçları

\begin{tabular}{|c|c|c|c|c|c|}
\hline Gecikme Değeri (lag) & CD & J pvalue & MBIC & MAIC & MQIC \\
\hline 1 & 0,9999863 & $0,0045464 *$ & $-75,80962 *$ & 1,471929 & $-28,75023^{*}$ \\
\hline 2 & $0,999972 *$ & 0,1569661 & $-43,51429$ & $-4,873517^{*}$ & $-19,9846$ \\
\hline
\end{tabular}

Optimal gecikme değerini hesaplamak için belirlenmiş 5 kriter bulunmaktadır. Bunlar: Yatay Kesit Bağımlılığı (CD), Hansen'in J testi (J pvalue), Düzeltilmiş Bayesyen Bilgi Kriteri (MBIC), Düzeltilmiş Akaike Bilgi Kriteri (MAIC) ve Düzeltilmiş Hannan-Quinn Bilgi Kriteri (HQIC)'dir. Bu kriterlerde mevcut olan minimum değer optimal gecikme sayısını vermektedir. Gecikme kriterlerinin çoğunluğunda minimum gecikme 1 düzeyinde olduğu için optimal gecikme sayısı 1'dir, Belirlenen optimal gecikme sayısına göre oluşan VAR modeli;

$\mathrm{PT}_{i t}=\mathrm{a}_{1}+\mathrm{b}_{1 \mathrm{i}} \mathrm{FG}_{\mathrm{it}-1}+\mathrm{b}_{2 \mathrm{i}} \mathrm{PF}_{\mathrm{it}-1}+\mathrm{b}_{3 \mathrm{i}} \mathrm{PT}_{\mathrm{it}-1}+\mathrm{v}_{1 \mathrm{t}}$

$F G_{i t}=c_{1}+d_{1 i} F_{i t-1}+d_{2 i} P F_{i t-1}+d_{3 i} P T_{i t-1}+v_{2 t}$

$P F_{i t}=e_{1}+f_{1 i} F G_{i t-1}+f_{2 i} P F_{i t-1}+f_{3 i} P T_{i t-1}+v_{3 t}$ şeklinde kurulmaktadır.

Optimal gecikme değeri tespit edildikten sonra, bu gecikme değeriyle yapılan panel VAR analizi sonuçları Tablo 8'de gösterilmiştir.

Tablo 8. Panel VAR Analizi Sonuçları

\begin{tabular}{|c|c|c|c|c|c|c|}
\hline InPT & Katsayı & Standart Hata & $\mathbf{z}$ & $P>|z|$ & \multicolumn{2}{|c|}{$\begin{array}{c}\text { \% } 95 \text { Güven Aralığı } \\
\text { Minimum / Maksimum }\end{array}$} \\
\hline InPT lag (1) & 0,9988955 & 0,0478513 & 20,87 & $0,000 *$ & 0,9051087 & 1,092682 \\
\hline InFG lag (1) & 0,034137 & 0,0208408 & 1,64 & 0,101 & $-0,0067103$ & 0,0749843 \\
\hline InPF lag (1) & $-0,0353989$ & 0,008435 & $-4,20$ & $0,000 *$ & $-0,0519312$ & $-0,0188667$ \\
\hline $\operatorname{lnFG}$ & Katsayı & Standart Hata & $\mathbf{z}$ & $P>|z|$ & \multicolumn{2}{|c|}{$\begin{array}{c}\text { \% } 95 \text { Güven Aralı̆̆ı } \\
\text { Minimum / Maksimum }\end{array}$} \\
\hline InPT lag (1) & 0,2532456 & 0,1046474 & 2,42 & $0,016^{*}$ & 0,0481405 & 0,4583506 \\
\hline $\operatorname{lnFG} \operatorname{lag}(1)$ & 0,9264499 & 0,0323798 & 28,61 & $0,000 *$ & 0,8629867 & 0,9899132 \\
\hline $\operatorname{InPF} \operatorname{lag}(1)$ & 0,0090382 & 0,0104248 & 0,87 & 0,386 & $-0,0113941$ & 0,0294705 \\
\hline InPF & Katsayı & Standart Hata & $\mathbf{z}$ & $P>|z|$ & \multicolumn{2}{|c|}{$\begin{array}{c}\text { \% } 95 \text { Güven Aralığı } \\
\text { Minimum / Maksimum }\end{array}$} \\
\hline InPT lag (1) & $-0,2795147$ & 0,3530497 & $-0,79$ & 0,429 & $-0,9714794$ & 0,41245 \\
\hline InFG lag (1) & $-0,0891275$ & 0,1608219 & $-0,55$ & 0,579 & $-0,4043326$ & 0,2260776 \\
\hline InPF lag (1) & 1,03863 & 0,0638366 & 16,27 & $0,000 *$ & 0,9135123 & 1,163747 \\
\hline
\end{tabular}

\%5 anlamlılık seviyesinde yapılan panel VAR analizi sonuçlarına göre; her değişkenin kendisiyle ve diğer değişkenlerin 1, gecikme değeriyle olan ilişkilerini göstermektedir. Her değişken kendisinin 1, gecikmesini \%5 anlamlılık seviyesinde açıklamaktadır. Ayrıca buna ilaveten; finansal gelişmişlik ile petrol tüketimi $(0,016<0,05)$ ve petrol tüketimi ile petrol fiyatlarının 1 , gecikmesi arasında $(0,000<0,05)$ anlamlı bir ilişki bulunmaktadır. Ancak bunların dışında değişkenlerin gecikmeleri arasındaki ilişki anlam ifade etmemektedir. VAR analizinin güvenilir sonuç verip vermediğini kontrol etmek için modelin istikrar koşulunu sağlaması gerekmektedir. VAR modeli istikrar koşulu sonuçları Şekil 1'de gösterilmiştir. 
Şekil 1. VAR İstikrar Koşulu

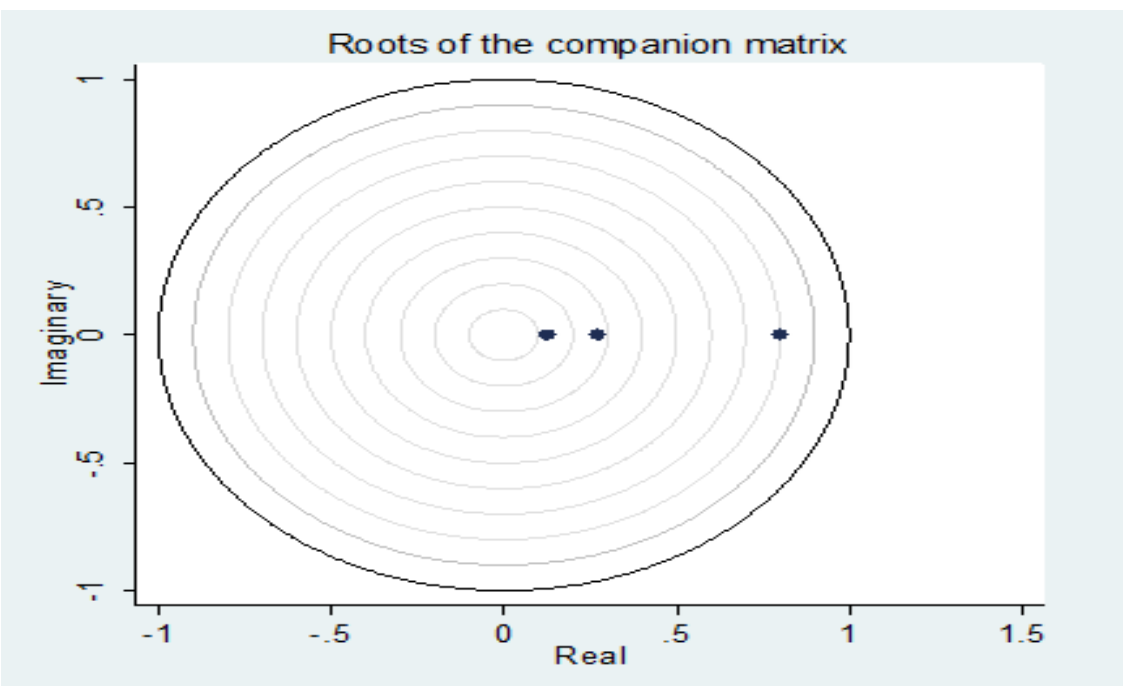

VAR modelinin istikrar koşulunu sağladığı görülmektedir. Çünkü modelde kullanılan değişkenlerin gecikmeleri ya da diğer bir ifadeyle sistemin karakteristik kökleri birim çemberin içerisinde bulunmaktadır. VAR istikrar koşulunun sağlanması güvenilir nedensellik sonuçlarına ulaşabilmek, sağlıklı etki-tepki grafikleri elde edebilmek için oldukça önemlidir. Ayrıca modeldeki gecikmelerin birim çemberin içerisinde yer alması farklı varyansa rastlanılmadığını da ifade etmekte ve bu nedenle varyans ayrıştırmasının yapılabileceğini göstermektedir.

\subsection{Panel VAR Granger Nedensellik Analizi}

Nedensellik analizi; iki değişken arasındaki neden-sonuç ilişkisine dayalı, değişkenler arasındaki ilişkiyi tespit eden, aralarındaki ilişkinin karşılıklı (çift yönlü) mı tek yönlü mü olduğunu belirlemeye yarayan analiz tipidir. Nedensellik analizleri ilk kez 1969 yılında Granger tarafından ortaya çıkarılmıştır. Granger nedensellik analizinde $\mathrm{x}$ değişkeninin modele eklenmesi $\mathrm{y}$ değişkeninin tahmin edilmesini sağlıyorsa $\mathrm{x}$ değişkeni $\mathrm{y}$ değişkeninin nedenidir. Bu sonuçlara ulaşabilmek için Granger nedensellik testinde aşağıdaki hipotezler test edilmektedir (Granger, 1969: 424-438):

$H_{1}: x, y^{\prime}$ nin Granger nedeni değildir.

$H_{2}: y, x^{\prime}$ in Granger nedeni değildir.

Bu hipotezlere göre; $H_{1}$ hipotezinin kabulü halinde $x$ değişkeni y'nin Granger nedeni değildir aksi durumda nedenidir. $\mathrm{H}_{2}$ hipotezinin kabulü halinde y değişkeni $x^{\prime}$ in Granger nedeni değildir aksi durumda nedenidir. Her iki hipotezin kabulü halinde değişkenler arasında nedensellik ilişkisi bulunmamaktadır. Her iki hipotezin reddi halinde ise değişkenler arasında çift yönlü nedensellik ilişkisi mevcuttur.

Engle ve Granger (1987) değişkenler arasında eşbütünleşme ilişkisi bulunduğunda VAR modeli ile yapılan nedensellik analizinin hatalı sonuçlara yol açtığı tespit edilmiş ve nedensellik analizinin hata düzeltme modelleri ile yapılması gerektiğini belirtilmiştir (Engle ve Granger, 1987: 251-276).

Panel veri analizinde nedensellik analizi ise her zaman bilinen standart Granger nedensellik analiziyle benzer şekildedir; ancak panel nedensellik analizinde heterojenliğin dikkate alınması oldukça önemlidir, aksi durumda farklı ve aldatıc sonuçlarla karşılaşılabilmektedir. Granger nedensellik analizinde heterojenliği dikkate alarak yapılan çalışmalar; Emirmahmutoğlu ve Köse (2011) ile Dumitrescu ve Hurlin (2012) ile literatüre kazandırılmıştır. Bu testlerin hepsinde modelde kullanılan değişkenlerin durağan olması gerektiği sıkça vurgulanmıştır (Emirmahmutoğlu ve Köse, 2011: 870-876; Dumitrescu ve Hurlin, 2012: 1450-1460).

Nedensellik analizinin teorisinin anlatılmasının ardından, bu araştırmada yapılacak nedensellik analizi sonuçları önem kazanmaktadır. Araştırmada modeldeki değişkenlerin durağan oldukları tespit edilmiş ve 
nedensellik sınaması Wald testi kullanılarak yapılmıştır, Wald testinde kurulan hipotezlerin doğruluğu; $F=$ ((HKTS - HKT) / r) / (HKT / ( $n-k)$ ) formülüyle hesaplanmaktadır. Bu formüldeki HKTS kısıtlanmış modelin hata kareleri toplamını, HKT kısıtlanmamış modelin hata kareler toplamını, $r$ kısıt sayısını, $n$ gözlem sayısını ve $k$ ise parametre sayısını göstermektedir. Uygulanan formül sonucunda hesaplanan $F$ değeri $F$ tablo değerinden büyükse $\mathrm{H}_{1}$ ve $\mathrm{H}_{2}$ hipotezi reddedilmektedir, Granger nedensellik testi sonuçları Tablo 9'da gösterilmiştir.

Tablo 9. Granger Nedensellik Analizi

\begin{tabular}{|l|c|c|c|}
\hline Değişkenler & Chi2 & df & Prob > chi2 \\
\hline $\ln F G \rightarrow \ln P T$ & 2,683 & 1 & 0,101 \\
\hline $\ln \mathrm{PF} \rightarrow \ln \mathrm{PT}$ & 17,612 & 1 & $0,000^{*}$ \\
\hline $\ln \mathrm{PT} \rightarrow \ln \mathrm{FG}$ & 5,856 & 1 & $0,016^{*}$ \\
\hline $\ln \mathrm{PF} \rightarrow \ln \mathrm{FG}$ & 0,752 & 1 & 0,386 \\
\hline $\ln \mathrm{PT} \rightarrow \ln \mathrm{PF}$ & 0,627 & 1 & 0,429 \\
\hline $\ln \mathrm{FG} \rightarrow \ln \mathrm{PF}$ & 0,307 & 1 & 0,579 \\
\hline
\end{tabular}

Granger nedensellik analizi sonuçlarına göre; petrol tüketiminden finansal gelişmişliğe doğru ve petrol fiyatlarından petrol tüketimine doğru tek yönlü nedensellik ilişkisine rastlanmıştır. Bu sonuç dışında; modeldeki diğer değişkenler arasında tek veya çift yönlü nedensellik bulguları tespit edilememiştir, Bu sonuca ulaşırken \%5 anlamlılık düzeyindeki ilişkiler incelenmiştir. Bulunan sonuçla " $\mathrm{H}_{1}: \mathrm{x}, \mathrm{y}$ 'nin Granger nedeni değildir" hipotezi reddedilmekte, petrol tüketiminin finansal gelişmişliğin ve petrol fiyatlarının petrol tüketiminin nedeni olduğu ispatlanmıştır. Ancak nedenselliğin çift yönlü olmadığı, sadece petrol tüketiminden finansal gelişmişliğe ve petrol fiyatlarından petrol tüketimine doğru bir nedensellik ilişkisi olduğu saptanmıştır.

\subsection{Varyans Ayrıştırması}

Varyans ayrıştırması; modeldeki değişkenlerin kendilerinde ve diğer değişkenlerinde meydana gelen şokları yüzdesel olarak göstermekte ve bu şokları değişkenlerin gecikmelerine göre ayrıştırmaktadır. Varyans ayrıştırması sistemin dinamik yapısı hakkında bilgi vermektedir. Varyans ayrıştırmasında; etki-tepki fonksiyonlarındaki gibi değişkenlerin sırası oldukça önemlidir, Çünkü kullanılan değişkenlerin yeri değiştikçe varyansları da farklılaşmaktadır. Varyans ayrıştırması; modelde kullanılan değişkenlerde meydana gelen herhangi bir değişimin yüzde olarak ne kadarının kendisinden ne kadarının diğer değişkenlerden kaynaklandığını göstermektedir. Değişkenlerdeki etkilenmenin çoğunluğu kendisinden kaynaklanan şoklardan ortaya çıkıyorsa bu değişken dışsal, şok diğer değişkenlerden kaynaklanıyorsa bu değişken içsel kabul edilmektedir. Ayrıca varyans ayrıştırması değişkenler arasındaki nedensellik ilişkilerinin derecesi hakkında da bilgi vermektedir (Enders, 1995: 311).

Bu çalışmadaki değişkenlerin varyans ayrıştırmaları Tablo 10 'da gösterilmiştir.

Her değişken için gösterildiğinden dolayı Varyans ayrıştırması sonuçları 3 bölüme ayrılmıştır. İlk tabloda petrol tüketimi üzerinde kendisi dışında petrol fiyatlarının yarattığı şok etkisi gecikme sayısı arttıkça yükselerek \%43 düzeyine ulaşmaktadır. İkinci tabloda ise finansal gelişmişlik değişkeni üzerinde kendisi ve diğer değişkenlerin yarattığı şoklar gösterilmiştir. Bu şoklar 10 gecikmeye kadar gösterilmiş ve finansal gelişmişlik değişkeni üzerinde petrol fiyatlarının yarattığı şoklar düşük iken kendisi ve petrol tüketiminin şok etkisi gözle görülür seviyededir. Petrol tüketiminin finansal gelişmişlik üzerinde oluşturduğu şok etkisi gecikme sayısı arttıkça yükselmekte ve \%34 seviyesine erişmektedir. Üçüncü tablodaki petrol fiyatları değişkeni incelendiğinde, petrol fiyatları üzerinde kendi gecikmesi dışındaki diğer değişkenlerin şok etkisi oldukça düşüktür. Bu sonuçlar; nedensellik analizinde ulaşılan petrol tüketiminden finansal gelişmişliğe doğru ve petrol fiyatlarından petrol tüketimine doğru tek yönlü nedensellik ilişkisini doğrulamaktadır. 
Tablo 10. Varyans Ayrıştırması

\begin{tabular}{|l|c|c|c|}
\hline \multicolumn{4}{|c|}{ Petrol Tüketimi Varyans Ayrıştırması } \\
\hline Dönem & InPT & InFG & InPF \\
\hline 1 & 1 & 0 & 0 \\
\hline 2 & 0,9768219 & 0,0014419 & 0,0217363 \\
\hline 3 & 0,9291111 & 0,0043632 & 0,0665257 \\
\hline 4 & 0,8667598 & 0,0081206 & 0,1251197 \\
\hline 5 & 0,7990632 & 0,0121333 & 0,1888034 \\
\hline 6 & 0,7328076 & 0,015993 & 0,2511995 \\
\hline 7 & 0,671994 & 0,0194706 & 0,3085353 \\
\hline 8 & 0,6184313 & 0,0224737 & 0,359095 \\
\hline 9 & 0,5725095 & 0,0249943 & 0,4024962 \\
\hline 10 & 0,533834 & 0,0270694 & 0,4390966 \\
\hline \multicolumn{4}{|c|}{ Finansal Gelişmişlik Varyans Ayrıștırması } \\
\hline Dönem & InPT & InFG & InPF \\
\hline 1 & 0,0001565 & 0,9998435 & 0 \\
\hline 2 & 0,0085797 & 0,9910553 & 0,0003649 \\
\hline 3 & 0,0266906 & 0,9728128 & 0,0004966 \\
\hline 4 & 0,0546147 & 0,9450012 & 0,0003842 \\
\hline 5 & 0,0919179 & 0,9071612 & 0,0009209 \\
\hline 6 & 0,1373942 & 0,8587919 & 0,0038139 \\
\hline 7 & 0,1888776 & 0,7998399 & 0,0112826 \\
\hline 8 & 0,2432332 & 0,7312311 & 0,0255356 \\
\hline 9 & 0,2966729 & 0,6552053 & 0,0481218 \\
\hline 10 & 0,3453969 & 0,57522 & 0,079383 \\
\hline \multicolumn{4}{|c|}{ Petrol Fiyatları Varyans Ayrıştırması } \\
\hline Dönem & InPT & InFG & InPF \\
\hline 1 & 0,0431086 & 0,0053968 & 0,9514946 \\
\hline 2 & 0,0529885 & 0,0035962 & 0,9434152 \\
\hline 3 & 0,0644496 & 0,0023613 & 0,933189 \\
\hline 4 & 0,0774814 & 0,0016924 & 0,9208262 \\
\hline 5 & 0,0920044 & 0,0015767 & 0,9064189 \\
\hline 6 & 0,107865 & 0,0019866 & 0,8901485 \\
\hline 7 & 0,1248373 & 0,0028783 & 0,8722844 \\
\hline 8 & 0,1426331 & 0,0041929 & 0,853174 \\
\hline 9 & 0,1609182 & 0,0058589 & 0,8332229 \\
\hline 10 & 0,1793355 & 0,0077961 & 0,8128685 \\
\hline \multicolumn{4}{|c|}{$\mid$}
\end{tabular}

\subsection{Etki-Tepki Fonksiyonları}

Etki-tepki fonksiyonları; hata terimlerindeki bir birimlik sapmanın modelin değişkenlerine olan etkisini göstermektedir. VAR analizinde dinamik ilişkileri, karşlıklı etkileşimi belirleyen ve gösteren etki-tepki fonksiyonlarıdır. Modeldeki değişkenler üzerinde hangi değişkenin ne derece etkili olduğu varyans ayrıştırması ile belirlenirken, etkin olan değişkenlerin grafiksel gösterimi ve genel geçer bir politikaya sahip olup olmadığı etki-tepki fonksiyonlarıyla yapılmaktadır. Ayrıca; etki-tepki fonksiyonlarında modeldeki değişkenlerin sırası oldukça önem arz etmektedir. Çünkü değişkenlerin sırası değiştikçe etki-tepki fonksiyonları farklılaşmaktadır. Etki-tepki fonksiyonlarında gerçek değerler yerine gerçek değerlerin olasılıklı değerleri güven aralıklarıyla ortaya konulmakta ve bu güven aralıkları Monte Carlo ve bootstrap gibi yöntemlerle hesaplanmaktadır. Hesaplanan güven aralığında gerçekleşebilecek standart hatalar da Monte Carlo simülasyonuyla belirlenmektedir (Lütkepohl, 2009: 281; Garita, 2011: 16).

Bu çalışmada değişkenler arasındaki etkileşimi gösteren grafikler Şekil 2'de gösterilmiştir. 
H. Bagci

Şekil 2. Etki-Tepki Grafikleri

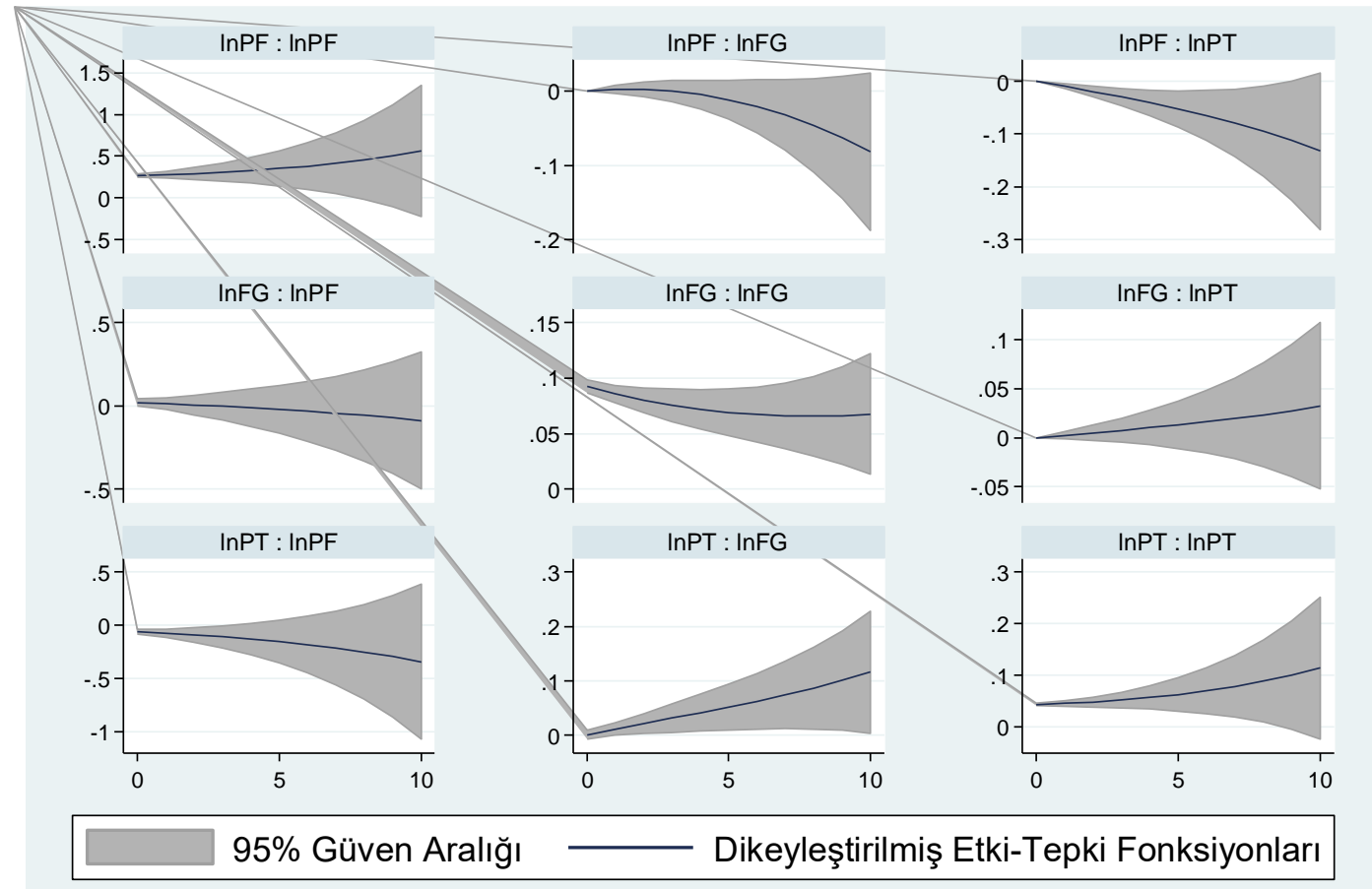

etki : tepki

Finansal gelişmişlik, petrol fiyatları ve petrol tüketimi arasındaki ilişki etki-tepki grafikleriyle gösterilmiştir. Bu grafikler \% 5 anlamlılık düzeyindedir ve hata terimlerindeki sapmaların modelin değişkenlerine etkisini göstermektedir. Her değişkenin kendi değişkeni ve diğer değişkenler üzerinde oluşturduğu etkiler grafiklerde görülmektedir. Petrol fiyatlarında oluşan bir birim şoka petrol tüketiminin vereceği tepki negatif yöndedir ve petrol tüketimi azalmaktadır. Aynı şekilde aralarında anlamlı bir ilişki bulunan petrol tüketimi ve finansal gelişmişlik grafiği incelendiğinde; petrol tüketiminde ortaya çıkan bir birim şoka finansal gelişmişliğin vereceği tepki pozitiftir ve finansal gelişmişlik artmaktadır. Bunun dışında sadece değişkenlerin kendi gecikmeleri üzerinde oluşturduğu değişiklikler anlamlıdır. Bu nedenle bütün grafikler yerine sadece aralarında anlamlı ilişki bulunan değişkenler hakkında yorumlarda bulunulmuştur.

\section{Sonuç ve Öneriler}

Dünya petrol ticareti; ekonomideki tüm değişkenleri etkilemekte ve ekonomik dengeleri bir anda tamamen değiştirebilmektedir. Bunun en temel nedeni; petrol fiyatlarındaki değişikliklerdir. Hatta ülkeler ekonomi ve siyasi politikalarını petrol fiyatlarındaki değişime göre oluşturmaktadır. Çünkü dünyada petrol fiyatlarını belirleyen OPEC gibi kartel kuruluşlar bulunmaktadır. Bu kuruluşlar; petrole olan arz ve talebe göre petrol fiyatlarını belirlemektedir ve 1973-1985 dönemi sonrası yaşanan petrol krizleri sonucu önemli konuma gelmiştir. OPEC; dünyada petrol ihraç eden ülkeler örgütüdür ve bu örgütü oluşturan ülkeler ağırlıklı olarak Orta Doğu'da bulunmaktadır. Bu bağlamda; Orta Doğu'nun dünya petrol piyasasına hakim olduğu görülmektedir.

Araştırmanın diğer konusu olan finansal gelişmişlik; son yıllarda ortaya çıkan ve yeni tanımlanan bir kavramdır. Aslan ve Korap (2006) finansal gelişmişliğin finansal genişleme ve finansal derinlik olmak üzere 2 kavramdan oluştuğunu ifade etmiş̧ir. Bu kavramların ortaya koyduğu finansal gelişmişlik tanımı ise finansal kurumların sayısı arttıkça ve finansal araçlar çeşitlendikçe finansal varlıkların gelire oranındaki artışın sağlanacağı yönündedir.

Finansal gelişmişliğin artması ülkelerin ekonomik büyümelerini hızlandırmaktadır. Finansal gelişmişliği arttırmak için ülkelerin etkin ve verimli bir finansal sisteme sahip olmaları gerekmektedir. Finansal sistemler fonksiyonlarını yerine getirebilmek için bankalardan ve sermaye piyasalarından yardım almaktadır. 
Finansal sistemlerin destek aldığı kuruluşa göre sistemleri şekillenmektedir. Yüksek finansal gelişmişlik hızı olan ülkelerde piyasa temelli sistem tercih edilmektedir. Çünkü piyasanın sunmuş olduğu finansal araçların hem çeşitliliği fazla hem de riski düşüktür.

Bu çalışmada; OECD ülkelerinin 1980-2015 yılları arasındaki petrol fiyatları ve petrol tüketimleri ile finansal gelişmişlikleri arasındaki ilişki incelenmiştir. Bu konunun araştırma problemi olarak seçilmesinin sebebi petrole bağımlı ülkelerin finansal durumunu tespit etmektir. Çünkü petrol piyasası sürekli değişkendir ve petrol piyasasındaki volatilitenin ülkelerin finansal gelişmişliği üzerinde oluşturduğu etki merak edilmektedir.

VAR analizinin ilk adımı olan Granger nedensellik analizi sonucunda; petrol tüketiminin finansal gelişmişliğin nedeni olduğu $(P T \rightarrow F G)$ ve petrol fiyatlarının petrol tüketiminin nedeni $(P F \rightarrow P T)$ olduğu saptanmıştır. Nedensellik analizi sonuçları, varyans ayrıştırmasıyla da desteklenmiş ve petrol tüketiminin finansal gelişmişliği açıklama yüzdesi gecikme sayısı arttıkça artarak \%34'e kadar ulaşmıştır. Aynı şekilde petrol fiyatlarının petrol tüketimini açıklama yüzdesi de artış göstermiş ve \%43 seviyesine yükselmiştir. Bu sonuçların dışında; her değişkenin kendi gecikmelerini açıklamakta olduğu tespit edilmiştir. Bulunan bu sonuçlar etki-tepki fonksiyonları yardımıyla grafiklerle gösterilmiş ve petrol tüketiminde yaşanan artışın finansal gelişmişliği arttırdığı ve petrol fiyatlarında yaşanan artışın petrol tüketimini düşürdüğü belirlenmiştir.

Bulunan bu sonuçlar literatürdeki çalışmalarla da desteklenmiştir, Mulali ve Sab (2012a) Sahra Altı Afrika Ülkeleri'nin 1980-2008 yılları arasındaki finansal gelişmişlikleri ve enerji tüketimleri arasındaki ilişki araştırmıştır. Panel granger nedensellik testi sonucunda enerji tüketimi arttıkça finansal gelişmişliğin arttığı ve enerji tüketiminden finansal gelişmişliğe doğru tek yönlü nedensellik ilişkisi tespit edilmiştir. Mulali ve Sab (2012b) gelişmiş ve gelişmekte olan 19 ülkenin enerji tüketimi ve finansal gelişmişlik ilişkileri Granger nedensellik testi yardımıyla ölçmüştür. Analiz sonucunda benzer biçimde enerji tüketiminin finansal gelişmişliğin nedeni olduğu ve enerji tüketimindeki artışın finansal geliş̧mişlik düzeyini yükselttiği saptanmıştır. Chang (2015) finansal gelişmişlik ve gelirin enerji tüketimi üzerindeki etkisini araştırmıştır. Bu çalışmada 53 ülkenin 1999-2008 yılları arasındaki yıllık verileri analize tabi tutulmuştur. Finansal gelişmişlik göstergeleri olarak 4 gelişmişlik göstergesinden yararlanılmıştır. Analizdeki ülkeler; gelir düzeyi yüksek olan ve olmayan ülkeler olarak sınıflandırılmıştır. Sonuç olarak; gelir düzeyi düşük ülkelerde enerji tüketiminin finansal gelişmişliği (gösterge olarak yurtiçi krediler ve özel sektör kredileri kullanıldığında) arttırdığı tespit edilmiştir. Gelişmekte olan ülkeler için ise finansal gelişmişlik göstergesi olarak borsa işlem hacmi ve borsa devir hızı oranları kullanıldığında enerji tüketiminin finansal gelişmişliği yükselttiği belirlenmiştir. Bu çalışmada kullanılan finansal gelişmişlik göstergelerine ve ülkelerin gelir düzeyine göre sonucun değişiklik gösterdiği ancak yine de enerji tüketiminin finansal gelişmişliği pozitif etkilediği saptanmıştır. Abbasi ve Riaz (2016) gelişen ekonomilerde finansal gelişmişlik ve $\mathrm{CO}_{2}$ emisyonu arasındaki ilişkiyi VAR analizi ile incelemiştir. Bu inceleme; 1988-2011 zaman diliminde ve Pakistan için gerçekleştirilmiştir. Analiz sonucunda; $\mathrm{CO}_{2}$ emisyonu ile finansal gelişmişlik arasında eşbütünleşme ilişkisine rastlanılmıştır. Finansal gelişmişlikleri artan ülkelerin $\mathrm{CO}_{2}$ emisyonunun azalmadığı aksine arttığı tespit edilmiştir. Bu çalışmada gelişen ekonomilerde de enerji tüketimi arttıkça finansal gelişmişliğin arttığı, çevreyi koruma ve enerji tüketimini azaltmanın ülkenin finansal gelişmişliğini arttırmayla çözülemeyeceği belirlenmiştir. Boz, Çınar ve Temelli (2017) Güneydoğu Asya Ülkeleri'nde (Çin, Japonya ve Güney Kore) enerji tüketimi, finansal gelişmişlik ve ekonomik büyüme ilişkisini 1985-2013 zaman dilimindeki yıllık veriler yardımıyla analiz etmiştir. Analizde değişkenler arasında eşbütünleşme ilişkisi belirlenmiş ve bu çalışmada her finansal gelişmişlik göstergesi tek tek incelenmiştir. Enerji tüketiminden finansal gelişmişlik göstergelerinden olan özel sektör kredilerine doğru nedensellik ilişkisi tespit edilmiştir. Sbia, Shahbaz ve Öztürk (2017)'ye göre; Birleşik Arap Emirlikleri'nde ekonomik büyüme, kentleşme, finansal gelişmişlik ve elektrik tüketimi arasındaki bağ ortaya konulmuştur. Bu çalışmada da elektrik tüketiminin finansal gelişmişliği arttırdığı ifade edilmiştir. Pradhan (2017) Granger nedensellik analizi yardımıyla finansal gelişmişlik ve enerji tüketimi etkileşimini belirlemiştir. Bu tespiti yaparken 35 ülkenin 1988-2012 yılları arası yıllık verilerden yararlanmış ve panel veri analizini kullanmıştır. Analiz sonucunda; finansal gelişmişlik ve enerji tüketimi arasında hem tek yönlü hem de çift yönlü nedensellik bulgularına ulaşılmıştır. Bunun nedeni olarak ise kullanılan göstergeler ve ülkelerin uygulamış olduğu farklı ekonomi politikaları gösterilmiştir. Tek yönlü nedensellik ilişkisi olarak; diğer çalışmalardakine benzer şekilde 
enerji tüketiminin finansal gelişmişliği pozitif yönde etkilediği ifade edilmiştir. Bu çalışmaların dışında literatürde enerji tüketiminin finansal gelişmişliği etkilediğini tespit eden; Sadorsky (2010), Sadorsky (2011), Shahbaz ve Lean (2012), İslam vd. (2012), Zeren ve Koç (2013) ve Alam vd. (2015) gibi çalışmalar bulunmaktadır. Ancak bu çalışmaların diğer çalışmalardan farkı; enerji tüketimi ve finansal gelişmişliğin ikisinin de birbirini etkilemesi ve aralarında çift yönlü nedensellik ilişkisi saptanmasıdır. Araştırmanın diğer değişkenleri arasındaki nedensellik ilişkisi ise petrol fiyatlarını etkileyen ekonomik etkenlerle ilişkilidir. Petrole olan arz-talep dengesine göre petrol fiyatları değişim göstermektedir. Çünkü talep yasasına göre bir malın fiyatı ile talep edilen miktarı arasında ters yönlü ilişki vardır. Bu nedenle bir malın fiyatı arttıkça tüketim miktarı azalmaktadır. Bu azalmanın sebebi; hem tüketicilerin ekonomik gelirleri hem de o malın ikamesi konumunda olan malların fiyatındaki düşüştür. Bu araştırmada petrolün fiyatı arttıkça petrol tüketim miktarının azaldığı biçiminde bu yasayı onaylayan bir bulguya ulaşılmıştır. Bu bulguyu ortaya petrol fiyatlarındaki artışın birçok nedeni bulunmaktadır. Petrol fiyatlarındaki artış; Çin, Rusya ve Hindistan gibi hızı büyüyen ve enerji ihtiyacı olan ülkelerin oluşturduğu baskıdan kaynaklanmaktadır. Ancak bu ülkelerdeki büyüme ve gelişme ABD ve Avrupa ekonomisini olumsuz etkilemektedir. Ayrıca petrol üreticisi olan OPEC ülkeleri, FED'in faiz indirim politikası, petrol piyasasındaki spekülasyonlar ve ABD'nin petrol rezervinin azalması gibi etmenler petrol fiyatlarını sürekli arttırmaktadır. Petrol fiyatlarındaki bu artış maliyeti arttırarak ülkelerdeki harcanabilir gelir miktarını azaltmakta ve dolayısıyla küresel tüketimi azaltmaktadır. Bu çalışmada da petrol fiyatlarının petrol tüketiminin nedeni olduğu ve petrol fiyatları arttıkça petrol tüketiminin azaldığı belirlenmiştir (Gürkan, 2009: 28-29; Eraydın, 2015: 2-16).

$\mathrm{Bu}$ çalışmanın bulguları literatürle desteklenmiş ve benzer sonuçlar açıklanmıştır. Ancak bu çalışmanın literatüre katkısı ve literatürden farklı yönleri de bulunmaktadır. Çalışmada kullanılan finansal gelişmişlik göstergeleri analize tek tek katılmak yerine bu göstergelerden bir endeks oluşturulmuş ve bu endeks oluşturulurken çok kriterli karar verme tekniklerinden Topsis yöntemi kullanılmıştır. Ayrıca enerji tüketimi ve finansal gelişmişlik ilişkisi bir bütün olarak incelenmemiş ve bunun yerine ülkeler için en önemli enerji kaynaklarından biri olan petrol kullanılmıştır. Diğer çalışmalara ilave olarak; kurulan modele fiyat değişkeni de eklenmiştir. Böylece; petrol fiyatı, tüketimi ve finansal gelişmişlik ilişkisi belirlenerek literatüre katkı sağlanmış ve çalışmaya özgünlük kazandırıımıştır.

Literatürdeki sonuçlarla desteklenen ve literatürden farkı ve özgünlüğü ortaya koyulan bu çalışmayla ilgili gelecekteki çalışmalara yön vermesi amacıyla birtakım tavsiyelerde bulunmak gerekirse; çalışmanın ülke grubu değiştirilerek analiz gerçekleştirilebilir, çalışmanın veri aralığı genişletilebilir, finansal gelişmişlik göstergeleri olarak kullanılan değişkenler farklılaştırılabilir, endeks hesaplamada kullanılan Topsis yöntemi yerine başka bir yöntem kullanılarak değişkenlerin önem dereceleri hesaplanabilir, finansal gelişmişlik endeksi oluşturmak yerine göstergeler tek tek kullanılarak panel veri seti oluşturulabilir, panel veri analizinde kullanılan VAR yöntemi yerine eğer değişkenler eşbütünleşik çıkıyorsa panel eşbütünleşme analizleri ve panel hata düzeltme modelleri ile analiz devam ettirilebilir ve bu çalışma literatürdeki benzer çalışmalarla karşılaştırılarak enerji ihtiyacı olan ülkelerin finansal durumları hakkında bilgi verebilmektedir.

\section{Son Notlar}

1. Bu çalışma yazarın doktora tezinden üretilmiştir.

2. Bu çalışma, 28-29-30 Kasım 2018 tarihlerinde düzenlenen "IV. International Conference on Applied Economics and Finance \& Extended with Social Sciences (ICOAEF'18)" kongresinde sözlü olarak sunulmuş ve öz kısmı Bildiri Özetleri Kitabında yayınlanmıştır.

\section{Teşekkür}

Yazar, doktora tezinde emeği geçen danışmanı Prof. Dr. Famil ŞAMiLOĞLU'na, analiz kısmına yardımcı olan ve kontrol eden Doç. Dr. Alessia SPADA'ya teşekkür eder. 


\section{Kaynaklar}

Abbasi, F., \& Riaz, K. (2016). $\mathrm{CO}_{2}$ emissions and financial development in an emerging economy: An augmented var approach. Energy Policy, 90, 102-114.

Alam, A. vd. (2015). Does financial development contribute to SAARC's energy demand? From energy crisis to energy reforms. Renewable and Sustainable Energy Reviews, 41, 818-829.

Aslan, Ö., \& Korap, L. H. (2006). Türkiye'de finansal gelişme ekonomik büyüme ilişkisi. Muğla Üniversitesi Sosyal Bilimler Enstitüsü Dergisi, 17(Güz), 1-20.

Aydın, C., \& Esen, Ö. (2017). Does too much energy consumption harm economic growth for Turkish Republics in the transition process? New evidence on threshold effects. International Journal of Energy Economics and Policy, 7(2), 34-43.

Aydın, C., \& Esen, Ö. (2018). Does the level of energy intensity matter in the effect of energy consumption on the growth of transition economies? Evidence from dynamic panel threshold analysis. Energy Economics, 69, 185-195.

Baltagi, B. H. (2012). Econometric analysis of panel data. Chichester: John Wiley \& Sons Publishing.

Boutabba, M. A. (2014). The impact of financial development, income, energy and trade on carbon emissions: Evidence from the Indian economy. Economic Modelling, 40, 33-41.

Brunnschweiler, C. N. (2009). Finance for renewable energy: an empirical analysis of developing and transition economies. Economics Working Paper Series, CER-ETH - Center of Economic Research at ETH Zurich.

Chang, S. C. (2015). Effects of financial developments and income on energy consumption. International Review of Economics and Finance, 35, 28-44.

Contuk, F. Y., \& Güngör, B. (2016). Asimetrik nedensellik testi ile finansal gelişme ekonomik büyüme ilişkisinin analizi. Muhasebe ve Finansman Dergisi, 71(Temmuz), 89-108.

Çelebi Boz, F., Çınar, Ö., \& Temelli, F. (2017). The relationship between energy consumption, financial development and economic growth: An analysis on the Asean countries. Balkan Journal of Social Sciences, 6(12), 36-52.

De Hoyos, E. R., \& Sarafidis, V. (2006). The testing for cross-sectional dependence in panel data model. The Stata Journal, 6(4), 482-496.

Demirci, N. S. (2017), Finansal gelişmişliğin özel sektör ar-ge harcamalarına etkisi: Türkiye için eşbütünleşme, nedensellik, etki-tepki analizleri ve varyans ayrıştırması (1990-2014). Muhasebe ve Finansman Dergisi, 74(Nisan), 157-182.

Dumitrescu, E., \& Hurlin, C. (2012). Testing for Granger non-causality in heterogeneous panels. Economic Modelling, 29, 1450-1460.

Emirmahmutoğlu, F., \& Köse, N. (2011). Testing for Granger causality in heterogeneous mixed panel. Economic Modelling, 28, 870-876.

Enders, W. (1995). Applied econometric time series. New York: John Wiley \& Sons Incorporation.

Engle, R. F., \& Granger, C. W. J. (1987). Co-integration and error correction: Representation, estimation and testing. Econometrica, 55(2), 251-276.

Eraydın, K. (2015). Petrol fiyatlarındaki düşüşün nedenleri ve etkileri. Türkiye İş Bankası.

Garita, G. (2011). The reciprocal relationship between systemic risk and real economic activity (MPRA Paper: 33135). 15.04.2017 tarihinde https://mpra,ub,uni-muenchen,de/33135/1/MPRA_paper_33135.pdf sayfasından erişilmiştir.

Granger, C. W. J. (1969). Investigating causal relations by econometric models and cross-spectral methods. Econometrica, 37(3), 424-438.

Greene, W. H. (1993). Econometric analysis (2nd Edition). New Jersey: Prentice Hall.

Güloğlu, B., \& İspir, S. (2009). Yeni gelişmeler ışığında Türkiye'de satın alma gücü paritesi önsavının panel birim kök sınaması. Denizli: Pamukkale Üniversitesi İktisadi ve İdari Bilimler Fakültesi İktisat Bölümü Yayınları.

Güriş, S. (2015). Stata ile panel veri modelleri. İstanbul: Der Yayınları.

Gürkan, M, (2009). Petrol piyasaları ve petrol fiyatlarının finansal piyasalar üzerine etkisi. Marmara Üniversitesi Sosyal Bilimler Enstitüsü, Yayınlanmamış Yüksek Lisans Tezi, İstanbul.

Gürkan, S., Çevik, E. I.., \& Korkmaz, T. (2014). Borsa istanbul'un gelişmiş ve gelişmekte olan ülke borsaları ile entegrasyonu. Bursa: Ekin Yayınevi.

Hausman, J. A. (1978). Specification tests in econometrics. Econometrica, 46(6), 1251-1271. 
Hsiao, C. (2003). Analysis of panel data (2nd Edition). New York: Cambridge University Press.

Islam, F., Shahbaz, M., Ahmed, A. U., \& Alam, M. (2013). Financial development and energy consumption nexus in Malaysia: A multivariate time series analysis. Economic Modelling, 30, 435-441.

Love, I., \& Zicchino, L. (2006). Financial development and dynamic investment behavior: Evidence from panel var. The Quarterly Review of Economics and Finance, 46, 190-210.

Lütkepohl, H. (2009). Econometric analysis with vector autoregressive models. Chichester: John Wiley \& Sons Ltd, UK.

Mulali, U., \& Sab, C. N. (2012a). The impact of energy consumption and $\mathrm{CO}_{2}$ emission on the economic growth and financial development in the Sub Saharan African countries. Energy, 39, 180-186.

Mulali, U., \& Sab, C. N. (2012b). The impact of energy consumption and $\mathrm{CO}_{2}$ emission on the economic and financial development in 19 selected countries. Renewable and Sustainable Energy Reviews, 16, 4365-4369.

Özer, M., \& Biçerli, K. (2003). Türkiye'de kadın işgücünün panel veri analizi. Anadolu Üniversitesi Sosyal Bilimler Dergisi, $3(1), 55-85$.

Özer, M., \& Çiftçi, N. (2009). Ar-Ge harcamaları ve ihracat ilişkisi: OECD ülkeleri panel veri analizi. Dumlupınar Üniversitesi Sosyal Bilimler Dergisi, 23, 39-49.

Özgen, F. B., \& Güloğlu, B. (2004). Türkiye'de iç borçların iktisadi etkilerinin VAR tekniğiyle analizi. ODTÜ Gelişme Dergisi, 31(1), 93-114.

Pazarlığlu, M. V., \& Gürler, Ö. K. (2007). Telekomünikasyon yatırımları ve ekonomik büyüme: Panel veri yaklaşımı. Finans Politik ve Ekonomik Yorumlar Dergisi, 44(508), 35-43.

Pesaran, M. H. (2012). Testing weak cross-sectional dependence in large panels. University of Cambridge and University of Southearn California CWPE 1208 Working Paper.

Pradhan, R. P. (2017). Granger causal nexus between financial development and energy consumption: Evidence from cross country panel data. International Journal of Economics and Management Engineering, 11(1), 26-29.

Sadorsky, P. (2010). The impact of financial development on energy consumption in emerging economies. Energy Policy, $38,2528-2535$.

Sadorsky, P. (2011). Financial development and energy consumption in central and eastern European frontier economies. Energy Policy, 39, 999-1006.

Sbia, R., Shahbaz, M., \& Öztürk, İ. (2017). Economic growth, financial development, urbanisation and electricity consumption nexus in UAE. Economic Research, 30(1), 527-549.

Shahbaz, M., \& Lean, H. H. (2012). Does financial development increase energy consumption? The role of industrialization and urbanization in Tunisia. Energy Policy, 40, 473-479.

Tunay, K. B. (2009). Türk bankacılık sektöründe rekabet ve kırılganlık. Bankacılar Dergisi, 68, 30-55.

Yao, Y. (2013). Three essays on financial development, economic growth and income inequality. The Chinese University of Hong Kong, Yayınlanmamış Yönetimsel Ekonomi Doktora Tezi, China.

Yerdelen Tatoğlu, F. (2013). Ileri panel veri analizi Stata uygulamalı (2. Baskı). İstanbul: Beta Basım Yayım Dağıtım.

Zeren, F., \& Koç, M. (2013). The nexus between energy consumption and financial development with asymmetric causality test: New evidence from newly industrialized countries. International Journal of Energy Economics and Policy, 4(1), 83-91. 